ANL -6306

ANL -6306

Argonne Rational 2 caboratoru

\author{
PHYSICS ANALYSIS OF \\ PROPOSALS FOR EBWR CORE 2 \\ by
}

R. Avery and C. N. Kelber 


\section{DISCLAIMER}

This report was prepared as an account of work sponsored by an agency of the United States Government. Neither the United States Government nor any agency Thereof, nor any of their employees, makes any warranty, express or implied, or assumes any legal liability or responsibility for the accuracy, completeness, or usefulness of any information, apparatus, product, or process disclosed, or represents that its use would not infringe privately owned rights. Reference herein to any specific commercial product, process, or service by trade name, trademark, manufacturer, or otherwise does not necessarily constitute or imply its endorsement, recommendation, or favoring by the United States Government or any agency thereof. The views and opinions of authors expressed herein do not necessarily state or reflect those of the United States Government or any agency thereof. 


\section{DISCLAIMER}

Portions of this document may be illegible in electronic image products. Images are produced from the best available original document. 


\section{LEGAL NOTICE}

This report was prepared as an account of Government sponsored work. Neither the United States, nor the Commission, nor any person acting on behalf of the Commission:

A. Makes any warranty or representation, expressed or implied, with respect to the accuracy, completeness, or usefulness of the information contained in this report, or that the use of any information, apparatus, method, or process disclosed in this report may not infringe privately owned rights; or

B. Assumes any liabilities with respect to the use of, or for damages resulting from the use of any information, apparatus, method, or process disclosed in this report.

As used in the above, "person acting on behalf of the Commission" includes any employee or contractor of the Commission, or employee of such contractor, to the extent that such employee or contractor of the Commission, or employee of such contractor prepares, disseminates, or provides access to, any information pursuant to his employment or contract with the Commission, or his employment with such contractor.

Price 75 cents . Available from the Office of Technical Services, Department of Commerce, Washington 25, D.C. 
ANL- 6306

Reactor Technology (TID-4500, 16th Ed.) AEC Research and Development Report

\section{ARGONNE NATIONAL LABORATORY \\ 9700 South Cass Avenue \\ Argonne, Illinois}

PHYSICS ANA LYSIS OF PROPOSALS FOR EBWR CORE 2

by

R. Avery and C. N. Kelber

Reactor Engineering Division

April 1961

Operated by The University of Chicago

under

Contract W-31-109-eng-38 
TABLE OF CONTENTS

$\underline{\text { Page }}$

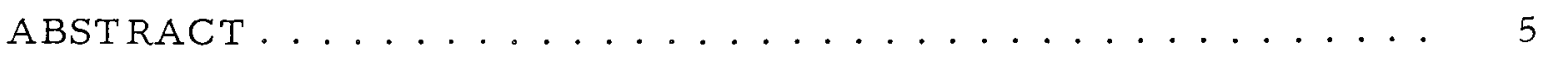

1. INTRODUCTION. ...................... 5

A. The Spiked Plutonium Recycle System ........... 5

B. Uniform and Two-zone Systems ............... 8

2. COMPOSITION CONSTANTS AND CROSS SECTIONS. ..... 10

A. Composition of Spiked System............... 10

B. Cross Sections for Spiked System .............. 11

C. Composition of Uniform and Two-zone Systems....... 12

D. Cross Sections for Uniform and Two-zone Systems ..... 15

3. AUXILIARY TABLES FOR AVERAGE AND REJECT BLANKET

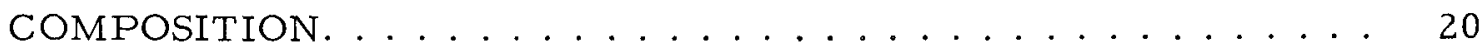

A. Final and Average Isotopic Compositions under Linear

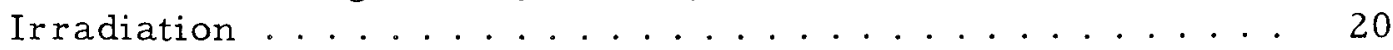

B. Final and Average Values of Isotopic Composition for the System Studied in This Report ............. 21

C. Error Introduced by the Assumption of Constant Thermal

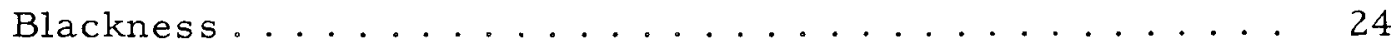

4. STUDY OF SPIKED PLUTONIUM RECYCLE SYSTEMS . . . . . 26

5. DISCUSSION OF RESULTS AND CONCLUSIONS ON SPIKED PLUTONIUM RECYCLE SYSTEMS. . . . . . . . . . 28

6. STUDY OF UNIFORM AND TWO-ZONE SYSTEMS ........ 32

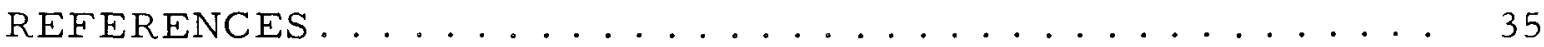




\section{LIST OF TABLES}

No.

Title

Page

1 Number Densities in Core 2 Spiked Configuration Studies . . 10

2 Estimated Disadvantage Factors (DF) and Fast Fission Factors, $\epsilon \ldots \ldots \ldots \ldots \ldots \ldots$

3 UNIVAC Cross Section Set $162 \ldots \ldots \ldots$

4 Lattice Characteristics, Uniform Core (Small Cell) . . . . 14

5 Number Densities in the Small Cell............. 15

6 Cross Sections in Barns $\left(10^{-24} \mathrm{~cm}^{2}\right)$ Used in Calculating $\epsilon .15$

7 Fast Fission Factor $\epsilon \ldots \ldots \ldots$

8 Resonance Integral Parameters for $\mathrm{U}^{238} \ldots \ldots \ldots$

9 Microscopic Thermal Cross Sections (Barns) and Estimated Disadvantage Factors $(\mathrm{DF}) \ldots \ldots \ldots 16$

10 UNIVAC Cross Section Set $163 \ldots \ldots \ldots$

11 Macroscopic Cross Section Set PDQ-3........... 19

12 Final and Average (for Linear Irradiation) Isotopic

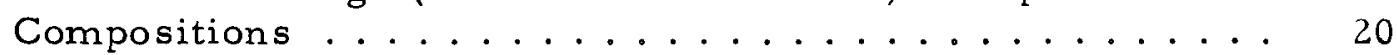

13 Final and Average (for Linear Irradiation) Blanket Compositions for Various Blanket Enrichments and Burnups of

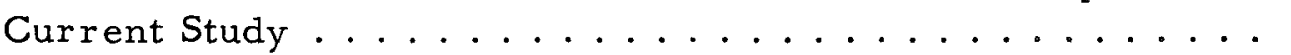

14 Final and Average (for Linear Ir radiation) Blanket Compositions for Various Blanket Enrichments and Burnups of

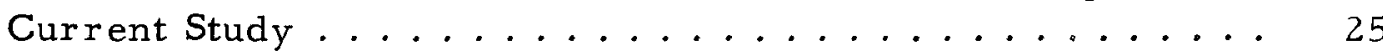

15 Summary of Results Obtained in Study of Spiked System ... 27

16 Equilibrium Characteristics of Homogeneous and Two-zone

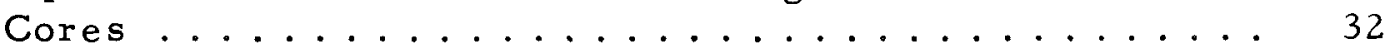

17 Burnable Poison Requirements of Homogeneous and Two-

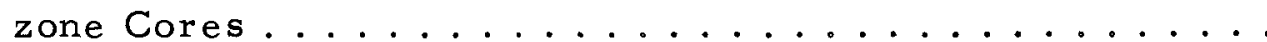

18 Effect of Burnable Poison Distribution on Two-zone Core $\left(\mathrm{E}_{0}^{\mathrm{II}} / \mathrm{EI}_{\mathrm{\delta}}=1.5\right) \ldots \ldots \ldots \ldots \ldots \ldots \ldots \ldots \ldots \ldots \ldots \ldots \ldots \ldots$

19 Control Rod Worth for Variable Distributions of Fuel and

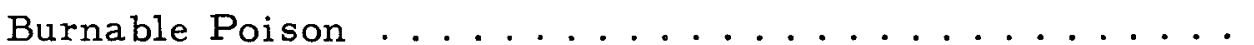




\title{
PHYSICS ANALYSIS OF PROPOSALS FOR EBWR CORE 2
}

\author{
by
}

R. Avery and C. N. Kelber

\begin{abstract}
Two concepts have been investigated as possibilities for the next loading of EBWR. One is a light water spiked plutonium recycle system; the second is a conventional uniformly loaded system with the option of different enrichments in two radial zones. It is concluded that the plutonium recycle scheme is not feasible in EBWR at $100 \mathrm{MW}$, and recommendation for a two-enrichment loading for various burnups is made.
\end{abstract}

\section{INTRODUCTION}

Two concepts have been under investigation as possibilities for the next loading of EBWR, Core 2. First, consideration has been given to a light water spiked plutonium recycle system. The basic features of this system are (a) a blanket or feed region (containing a large amount of fertile material) comprising most of the core, and (b) a relatively small number of spiked elements (containing fissile but no fertile material). Second, a more conventional uniformly loaded system has also been considered, with the option of different enrichments in two radial zones allowed. This report gives results of further investigation into the characteristics and potential of the two concepts.

\section{A. The Spiked Plutonium Recycle System}

The following mode of operation is envisaged for the system. Blanket (or feed) elements are periodically loaded into the reactor in batches and subsequently shuffled about so that a reasonable approximation to a uniform irradiation is obtained. When a blanket element has reached the specified reject burnup, it is removed from the reactor and processed. The uranium is rejected insofar as further use in the cycle is concerned. The plutonium is separated out and is available for replenishing the fuel in the spiked elements. The spikes, containing only plutonium among the heavy isotopes, are periodically reprocessed with plutonium being added as necessary. Although the concept is based on a plutonium spike, early investigatory loadings might well use a $\mathrm{U}^{235}$ spike so this case has also been considered. 
Consideration of this concept is motivated by the possibility of a number of potential advantages. Although it is not obvious that these advantages can all, or even in part, be realized, the characteristics of an ideal spiked system are the following:

(a) Low-enrichment (preferably natural uranium) feed material.

(b) Large fractional burnup of the feed material.

(c) Plutonium recycle operation - in this particular concept this means that sufficient plutonium is removed from the blanket material to supply the plutonium required for the spikes.

(d) A relatively flat power distribution; in particular, one would like to avoid any appreciable power peaks in the spikes, since such peaks may limit the total power of the system either from heat transfer or stability considerations.

(e) A low reject $\mathrm{U}^{235}$ concentration in the blanket. This quantity is related to the fractional burnup of feed material and would be particularly important if slightly enriched rather than natural uranium were used.

A potential advantage of the spiked system is that, through reactivity enhancement, irradiations that are not otherwise possible may be allowed. For example, the spiked system may permit the use of feed material of lower enrichment; or conversely it may permit larger burnups of the feed material of a given enrichment.

Another potential advantage relates to possible simplification and economies in the reprocessing procedures in the spiked recycle as opposed to a uniformly loaded recycle system. This aspect of the problem has not at all been considered in the present study, however, and is not further discussed.

There are many inherent conflicting requirements in the design of a spiked system. For example, in order to satisfy the plutonium recycle requirement most easily, it is desirable that the amount of plutonium burned in the spikes be kept as low as possible. In order for the necessary reactivity enhancement to occur without too great a total number of fissions in the spikes, it is necessary for the plutonium region to be rather compact. The latter requirement may result in large power peaks in the spikes, and in turn lead to a low average power.

The following is another example of conflicting requirements in the design. It would be advantageous from plutonium recycle considerations to irradiate the blanket material to a low burnup in order to increase the amount of plutonium available for recovery from the blanket. However, this is clearly in conflict with the objective of obtaining substantial burnup in the blanket material. 
It can be seen that the problem of evaluation of the potential of the spiked plutonium recycle system is essentially one of determining whether a sufficiently attractive compromise can be obtained with all of the different conflicting requirements.

The results of the study on the spiked system are given in Section 4. Both large systems, typical of full-scale plants, and small systems, typical of EBWR, were considered. For the small systems, $U^{235}$ spikes were considered in addition to the plutonium spikes, since initial EBWR fuel loadings would probably be with $U^{235}$ spikes.

The study is primarily based on an analysis of the equilibrium condition. It is assumed that the blanket is undergoing continuous fuelmanagement procedures so that the burnup history of each element is identical. At any time the blanket is composed of material at various stages of irradiation, extending from zero burnup all the way to the reject burnup. The distribution of fuel in terms of relative amounts of blanket material is linear as a function of the irradiation measured in integrated flux time. In the calculations the spikes are assumed also to be at an equilibrium composition. Actually, of course, the spike will be loaded and unloaded on a cyclical basis. It would probably be done on a batch basis and, furthermore, the cycle time is rather short compared to the blanket cycle time. For both these reasons the assumption of a spike composition, constant in time, corresponding to the average composition over the spike irradiation is valid.

The variables for the large system were (1) the inıtial blanket enrichment; (2) the burnup of the reject blanket material (approximately equal to twice the average burnup of the blanket); and (3) the dimensions of the spiked region. The variables in the study on the small $\mathrm{Pu}^{239}$ and $\mathrm{U}^{235}$-spiked systems were in general the same, although only a single spike dimension was considered, this dimension being largely determined by the location of the EBWR control rods. The loading of the spiked region necessary for criticality was determined for each case considered.

The criteria by which the spiked systems are to be evaluated are specified by the original objectives and characteristics of the ideal spiked system. It is useful to elaborate on one of the criteria that is used in both this and previous studies of spiked recycle systems: the production ratio, defined as the ratio of the amount of plutonium removed from the blanket to the amount of plutonium burned in the spikes. A value of unity or greater - corresponds to a self-sustaining system, insofar as the plutonium inventory is concerned. Although this number is useful, importance should be attached to it only to the extent that other desirable objectives are simultaneously obtained. This is so because as large a value for the production ratio as desired can be attained if other objectives are sufficiently compromised. To attain a high value, it is only necessary that the blanket be 
sufficiently enriched so that only a negligible amount of spike is required. The production ratio is also enhanced if the blanket is processed at low burnups. One should, therefore, be careful in the use of the production ratio as an evaluation criterion, particularly at high blanket enrichments.

B. Uniform and Two-zone Systems

During the study of the plutonium-spiked recycle system there was substantial doubt, later justified, that a suitable compromise could be found for all the conflicting requirements. A parallel study on a uniformly loaded system was undertaken.

For the uniform system the question was not one of feasibility of concept. Therefore the study concentrated on EBWR with the practical limitations imposed by the existing facility taken into consideration.

In order to improve the power distribution in the system, the option of different enrichments in two radial zones was allowed in the study.

From considerations of neutron economy and long-term reactivity, a tight lattice improves performance. For this reason the study was based on a tight lattice that, with some radial power flattening, permits operation at $100 \mathrm{Mwt}$.

A number of cases were considered in the study. For each case, characterized by the burnup of the reject material and by the ratio of enrichments in the two radial zones, the necessary enrichment of the feed material was determined. The reactivity that is available for longterm burnup must be held down in initial operation and in the approach to equilibrium. The reactivity that is available in the control rod system of EBWR is of the order required for reactivity swings from cold shutdown to hot operating conditions and nothing appreciable is left over for longterm burnup compensation. It is assumed that the necessary control will be primarily obtained through the use of burnable poisons, and the amount required at various points in the approach to equilibrium was determined.

The two-zone phase of the study was based on an inner zone consisting of the innermost eight-by-eight array of elements in EBWR. Various enrichment ratios in the two zones were considered in order to obtain the optimum power distribution.

The entire study for both the spiked and uniform systems was based on the use of uranium dioxide fuel. The spikes were assumed to contain either plutonium or uranium dioxide dispersed in an aluminum matrix.

The entire study was also based on an EBWR core height of four feet. The reduction from a previously contemplated height of five feet is based on tentative conclusions from both heat transfer and physics 
considerations that no particular advantage accrues from the use of the five-foot core. Furthermore, a serious hot spot problem resulting from the maximum three-foot fuel follower length is thus circumvented.

Even though the use of aluminum clad had been tentatively decided upon for Core 2, it was convenient to base the present study on the use of a zirconium clad. The choice between aluminum and zirconium clad should have a negligible effect on the results of this study. The tentative plan to use aluminum, which was made when it appeared that the spiked system would be the one installed in EBWR, will be re-appraised if the emphasis goes over to the long-irradiation, uniform system. 


\section{COMPOSITION CONSTANTS AND CROSS SECTIONS}

A. Composition of Spiked System

The study of the spiked system was not based on a specific design for the fuel element but was based on an assumed typical composition.

Table 1 lists the atom densities in the blanket and spike regions for hot operating conditions at 0 voids $(\mathrm{V}=0)$ and 0.6 voids $(\mathrm{V}=0.6)$. The atomic densities given in Table 1 correspond to the "large" unit cell in EBWR associated with "Class A" cross sections as defined in Ref. 2, in which the basis is taken as the repeating 9-element sublattice of the EBWR, 12.75 in $(32.385 \mathrm{~cm})$ square, complete with its adjoining control rod channels, spacers and other structural materials. Stainless steel fueled followers are incorporated into the composition.

Table 1

NUMBER DENSITIES IN CORE 2 SPIKED CONFIGURA TION STUDIES

\begin{tabular}{|c|c|c|}
\hline \multirow[b]{2}{*}{ Element } & \multicolumn{2}{|c|}{$\mathrm{N}\left(\mathrm{x} 10^{-24}\right)$, atoms $/ \mathrm{cm}^{3}$} \\
\hline & Blanket & Spike \\
\hline $\mathrm{U}^{235}$ & $0.0000347 \mathrm{~L}_{\mathrm{B}}$ & $0.0000347 \mathrm{~L}_{\mathrm{S}}$ \\
\hline $\mathrm{U}^{238}$ & 0.00479 & \\
\hline $\mathrm{O}^{(1)}$ & 0.00958 & \\
\hline A 1 & 0 & 0.01294 \\
\hline $\mathrm{Zr}$ & 0.00624 & 0.00624 \\
\hline $\mathrm{H}_{2} \mathrm{O}, \mathrm{V}=0$ & 0.01576 & 0.01576 \\
\hline $\mathrm{H}_{2} \mathrm{O}, \mathrm{V}=0.6$ & 0.00630 & 0.00630 \\
\hline $\mathrm{U}^{235(2)}$ & 0.0000052 & 0.0000052 \\
\hline $\mathrm{Fe}$ & 0.00256 & 0.00256 \\
\hline
\end{tabular}

(1) This is the oxygen in $\mathrm{UO}_{2}$ only; the oxygen in the water is included in the $\mathrm{H}_{2} \mathrm{O}$.

(2) This is the $U^{235}$ in the fueled followers.

(3) The use of $L_{B}$ and $L_{S}$ is explained in the text. $L_{B}=1$ corresponds to a blanket fueled with natural uranium. 
The detailed geometrical description may be found in Ref. 2 , but is not important for the present considerations. The condition $L=1$ for either the blanket $\left(L_{B}=1\right)$ or for the spike $\left(L_{S}=1\right)$ corresponds to an atomic concentration equal to that of $\mathrm{U}^{235}$ in a blanket element containing natural uranium. This unit is used for plutonium isotopes as well as for $\mathrm{U}^{235}$.

The basic fuel element used in computing the cross section has the same composition as the thick enriched elements in EBWR Core 1 (see Ref. 2). The uranium, however, is replaced by an equal volume of $\mathrm{UO}_{2}$ $\left(\rho=9.5 \mathrm{gm} / \mathrm{cm}^{3}\right)$ or of $\mathrm{Al}-\mathrm{U}^{235}$ (or $\left.\mathrm{Pu}^{239}\right)$ mixture $\left(\rho_{\mathrm{Al}}=2.43 \mathrm{gm} / \mathrm{cm}^{3}\right)$ for the blanket or spike regions, respectively.

B. Cross Sections for Spiked System

The general methods used in obtaining cross sections for the EBWR Core lA study (Ref. 2) were also used here. Most of the details will not be repeated.

In the present study, the Sofocate (Ref. 3) code for obtaining cross sections averaged over a Wigner-Wilkins spectrum was used directly instead of Amster's compilation (Ref. 4) for the evaluation of thermal cross sections; the two are equivalent, since the Amster compilation is obtained by use of the Sofocate code.

The thermal cross sections for $U^{235}$ and the plutonium isotopes were evaluated in spectra characteristic of zero void and also 0.6 void. The cross sections at operating voids were obtained by taking the suitable linear combination.

As in previous work on Core lA (Ref. 2), $\nu=2.43$ (corresponding to $\eta=1.05$ ) was used for $\mathrm{U}^{235}$. All $\nu \sigma_{\mathrm{f}}^{\prime}$ 's were divided by 1.05 to allow for $\mathrm{Xe}$ and $\mathrm{Sm}$ and also as an allowance for error.

The disadvantage factors and fast fission factors used for the blanket and spike elements are given in Table 2 .

Table 2

ESTIMATED DISADVANTAGE FACTORS (DF) AND FAST FISSION FACTORS (E)

$\begin{array}{lccc}\text { Region } & \text { DF, moderator } & & \text { DF, fuel } \\ \text { Spike } & 1.05 & 0.975 & 1.00 \\ \text { Blanket } & 1.05 & 0.975 & 1.03\end{array}$


The resonance integral of $\mathrm{U}^{238}$ is dependent on the surface-to-mass ratio in the blanket rods. A representative value of $p=0.8$ at hot operating conditions for reasonably sized rods ( $\sim 1 \mathrm{~cm}$ diameter) was used.

Resonance integrals were the same as those used in Ref. 2, except for $\mathrm{Pu}^{240}$, the value for which was taken to be $1500 \mathrm{~b}$ from the curve in Ref. 5, p. 235, and is more representative for the higher burnups.

The cross sections of the reflector water are the same as those reported in Ref. 2. A fictitious material having the properties of a $1 / \mathrm{v}$-absorber was used to represent fission products.

Macroscopic Cross-section Set

The cross-section set used for this phase of the study is designated as Univac Cross Section Set 162 and is given in Table 3. Also included in the table are the formulae for the volume fractions of the materials. Macroscopic cross sections are given for various, sometimes fictitious, materials, and regions are then defined as linear combinations of these materials. It is convenient to take as four basic materials the spike elements at 0 and 0.6 void and the blanket elements at 0 and 0.6 void, for which in all cases the basic materials contain no fissionable material except for that in the fueled followers. The compositions of these materials are given in Table 1 when $L_{B}$ and $L_{S}$ are set equal to zero.

The absorption cross sections of $U^{235}$ and the plutonium isotopes have been divided by 1.03 in order to account for the fast fission factor, $\epsilon$, in the blanket. The volume fractions of these materials are then increased by the factor $\epsilon$ so that in the blanket (where $\epsilon=1.03$ ) the proper relationship between $\nu \Sigma_{\mathrm{f}}$ and $\Sigma_{\mathrm{a}}$ is obtained. In the spike, $\epsilon=1$, and the reduction in the macroscopic absorption cross section must be compensated by the addition of a suitable amount of " $1 / v$ " absorber; this leads to a small negligible error in the group 2 absorption.

The variation with void in effective absorption and fission cross sections of $\mathrm{U}^{235}$ and the plutonium isotopes is allowed for by inserting the cross-section values at zero voids in Cross Section Set 162 and then multiplying the volume fraction of material $j$ by a factor $\left(1+\alpha_{j} V\right)$ where $V$ is the void fraction. The coefficient $\alpha_{j}$ is deduced from the assumed linear variation of cross section between $V=0$ and $V=0.6$. The $\alpha_{j}$ are given in the notes for Table 3 .

\section{Composition of Uniform and Two-zone Systems}

Studies of a uniform core loading or a two-enrichment loading were based on a design which had the characteristics listed in Table 4. The clad material was assumed to be zirconium for the purpose of these studies. (A change to aluminum should not affect the results appreciably.) 
Table 3

UNTVAC CROSS SECTION SET 162

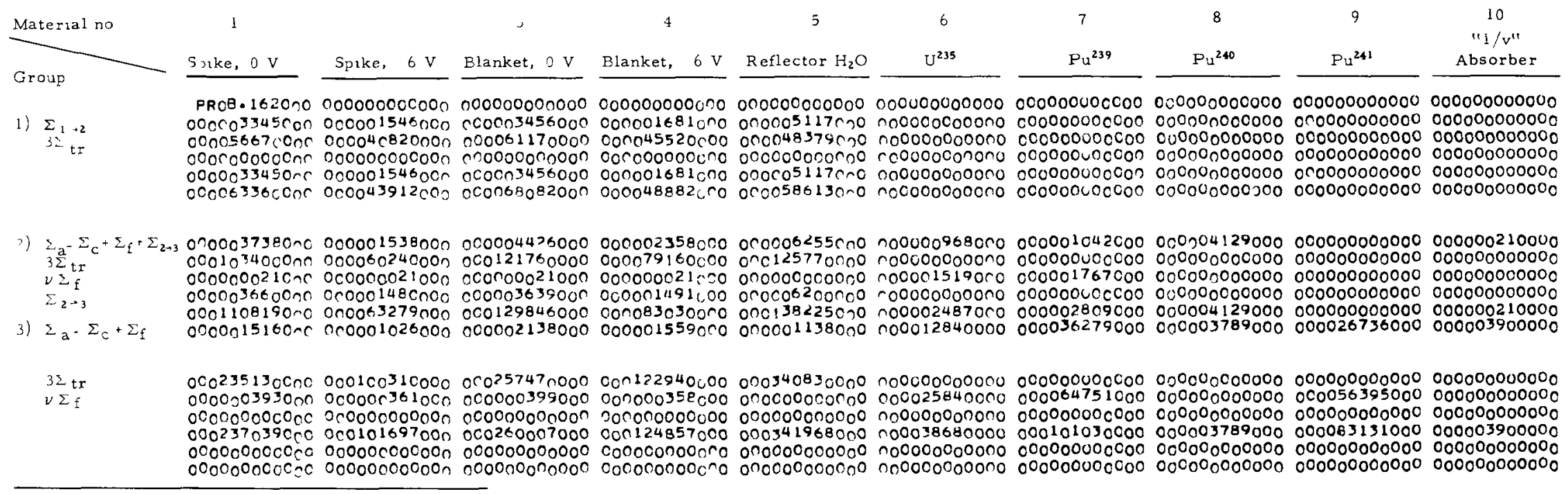

All cross sections are in units of $\mathrm{cm}^{-1}$ Fission neutrons are born in group 1 Decimal point 15 between 4 th and 5 th $f_{1}$ gures in all of above numbers

Volume fraction formulae

(V - void fraction, N - atomic density $\left.\times 10^{-24}\right)$

\begin{tabular}{|c|c|c|c|}
\hline Material & Volume Fraction (VF) & Material & Volume Fraction (VF) \\
\hline Spike, $V=0$ & $1-(v / 06)$ & $6 \mathrm{U}^{235}$ & $\mathrm{~N} \in(1-015 \mathrm{~V}) / 0000347$ (where $c=1$, add material 10 as indicated) \\
\hline Spike, $V=06$ & $\mathrm{v} / 06$ & $7 \mathrm{Pu}^{239}$ & $\mathrm{~N} \in(1+0133 \mathrm{~V}) / 0000347$ (where $\epsilon=1$, add material 10 as indicated) \\
\hline Blanket, $\mathrm{V} \quad 0$ & $1-v / 06$ & $\mathrm{Pu}^{240}$ & $N / 0000347$ \\
\hline Blanket, $\mathrm{V}=06$ & $\mathrm{v} / 06$ & $\mathrm{Pu}^{241}$ & $N \in(1-0131 \mathrm{~V}) / 0000347$ (where $\epsilon \quad 1$, add material 10 as indicated) \\
\hline Reflector $\mathrm{H}_{2} \mathrm{O}$ & $(1-v)$ & $10 " 1 / v "$ absorber & Where $c=1, \operatorname{VF}\left(\right.$ Material 10) $01 \mathrm{VF}\left(\mathrm{U}^{235}\right)+0279 \mathrm{VF}\left(\mathrm{Pu}^{239}\right)+0205 \mathrm{VF}\left(\mathrm{Pu}^{241}\right)$ \\
\hline
\end{tabular}

cross section at $2200 \mathrm{~m} / \mathrm{s}$ of 60 barns Then if the
account for fission products is $0269 \mathrm{~F} / 0000347$ 
Table 4

LATTICE CHARACTERISTICS, UNIFORM CORE (Small Cell)

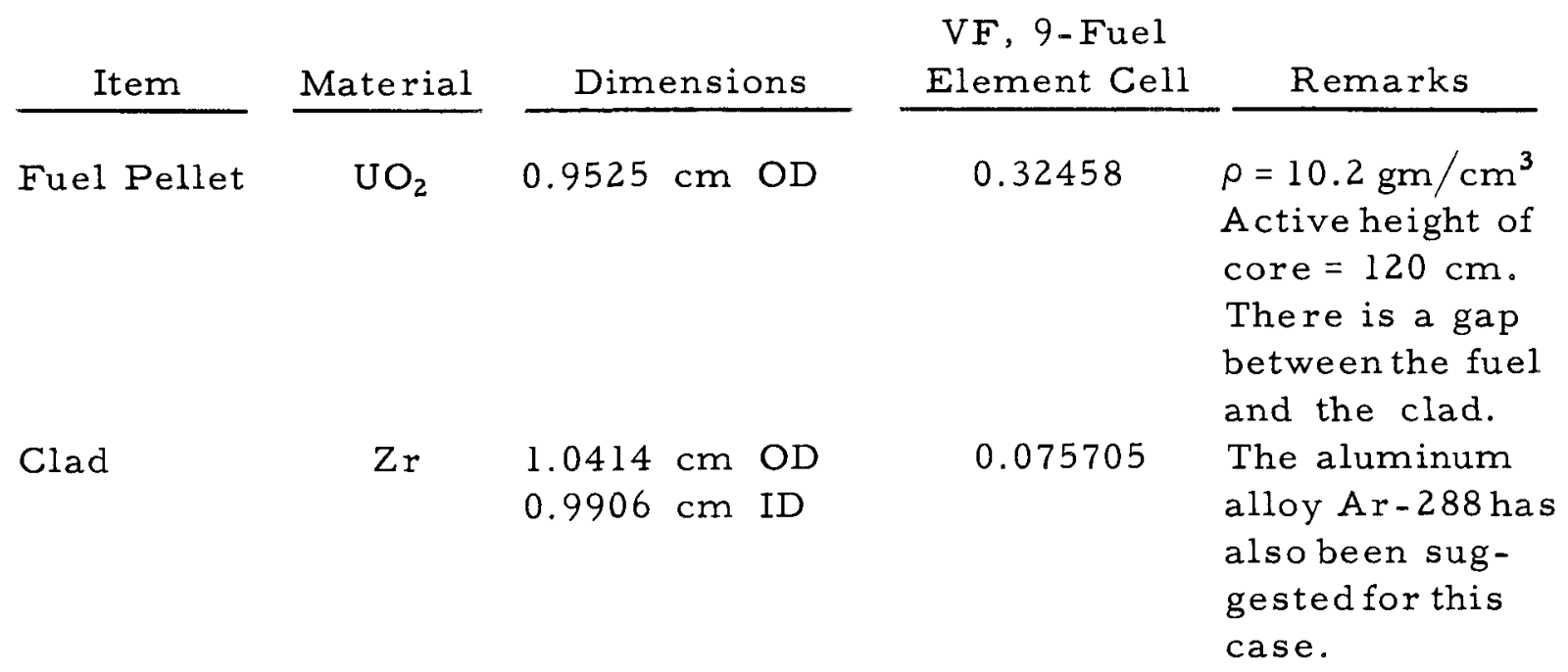

Fuel Box

$\mathrm{Zr} \quad$ Four plates, 9.525

0.056226

Same as above. $\mathrm{cm}$ long by 0.15875

$\mathrm{cm}$ thick

Control Rod

Zr

Four plates,30.7975

0.040399

Guides

$\mathrm{cm}$ long by 0.3175

cm thick (9-ele-

ment cell)

Zr Rod

These items are the same as in Reference 2, Section 3.

Follower

Spacer

Core Water

It

Reflector Water

II

"1

In addition to the fuel element cladding, other structure present (see Ref.2) includes: box material (also assumed to be $\mathrm{Zr}_{r}$ ); control rod guides ( $\mathrm{Zr}$ ); control rod followers $(\mathrm{Zr})$; and spacer material ( $\mathrm{Zr}$ and $\mathrm{H}_{2} \mathrm{O}$ ).

The number densities in the "small" $31.115-\mathrm{cm}$ square cell (excludes control rod guides and channels; see Ref. 2) are given in Table 5. The composition of the "large" cell $(32.385 \mathrm{~cm} \mathrm{sq})$ is obtained by combining the materials of the small cell with core water, rod followers, and spacer material in the proportions $0.9231: 0.0302: 0.0302: 0.0165$. 
Table 5

\section{NUMBER DENSITIES IN}

\section{THE SMALL CELL}

$\begin{array}{ll}\text { Element } & \mathrm{N}\left(\mathrm{x} 10^{-24}\right), \text { atoms } / \mathrm{cm}^{3} \\ \mathrm{H} & 0.03313 \rho(1-\mathrm{V}) \\ \mathrm{O} \text { in } \mathrm{H}_{2} \mathrm{O} & 0.01656 \rho(1-\mathrm{V}) \\ \mathrm{Zr} & 0.007290 \\ \mathrm{U} & 0.007378 \\ \mathrm{O} \text { in } \mathrm{UO}_{2} & 0.01476\end{array}$

$$
\begin{aligned}
& \rho=\text { density of wate } r, \mathrm{gm} / \mathrm{cm}^{3} \\
& V=\text { void fraction }
\end{aligned}
$$

\section{Cross Sections for Uniform and Two-zone System}

Cross sections were calculated for the small cell in order that cold shutdown problems could be studied. Control rods and channels could then be considered as separate regions. Cross sections pertaining to the large cell $(32.385 \mathrm{~cm} \mathrm{sq})$ are found by homogenizing the small cell cross sections with those of core water, rod follower, and spacer material in the proportions $0.9231: 0.0302: 0.0302: 0.0165$.

The fast fission factor $\epsilon$ was calculated by the methods given in Ref. 5, pp. 127, 355. The cross sections used in the $\epsilon$ calculation are given in Table 6, and $\epsilon$ is given in Table 7 .

\section{Table 6}

\begin{tabular}{|c|c|c|c|c|}
\hline Element & ${ }^{\sigma} \mathrm{c}$ & $\sigma_{f}$ & $\sigma_{\text {in }}$ & $\sigma_{\text {tot }}$ \\
\hline$U^{235}$ & 0.1 & 1.3 & 1.4 & 2.8 \\
\hline$U^{238}$ & 0.04 & 0.53 & 2.1 & 2.67 \\
\hline $\mathrm{H}$ & & & 1.32 & 1.32 \\
\hline 0 & 0.24 & & 0.17 & 0.194 \\
\hline $\mathrm{Zr}$ & & & 0.8 & 0.8 \\
\hline
\end{tabular}

$\frac{\text { CROSS SECTIONS IN BARNS }\left(10^{-24} \mathrm{~cm}^{2}\right)}{\frac{\text { USED IN CALCULATING } \epsilon}{\text { (Cross sections averaged over spec- }}}$


The resonance integral of $\mathrm{U}^{238}$ was calculated by the methods of Vernon (Ref. 6). The Dancoff correction to the surface term was made using the formulae given in Ref. 5, pp 345-346. The results of these calculations are reported in Table 8 . The resonance integrals for $\mathrm{U}^{235}$ and the $\mathrm{Pu}$ isotopes are the same as those used in Ref. 2, except that $\mathrm{Pu}^{240}$ is assigned a resonance integral of $1500 \mathrm{~b}$ as in the study of spiked configurations.

Table 8

Table 7

\begin{tabular}{|c|c|c|c|c|c|}
\hline FAST FISSION & FACTOR $\epsilon$ & Condition & $\begin{array}{c}\text { Dancoff Correction } \\
\text { Factor C } \\
\end{array}$ & $\begin{array}{c}\text { Resonance Integral } \\
\text { (barns) }\end{array}$ & $\mathrm{p}$ \\
\hline Condition & $\epsilon$ & Cold & 0.4856 & 16.35 & 0.8425 \\
\hline $\begin{array}{l}\text { Cold } \\
\text { Hot, } V=0\end{array}$ & $\begin{array}{l}1.035 \\
1.039\end{array}$ & Hot, $V=0$ & 0.43472 & 17.62 & 0.7942 \\
\hline Hot, $V=0.4$ & 1.047 & Hot, $\mathrm{V}=0.4$ & 0.30692 & 19.04 & 0.6640 \\
\hline
\end{tabular}

Thermal microscopic cross sections of materials in the fuel box and the associated estimated disadvantage factors are given in Table 9.

Table 9

MICROSCOPIC THERMAL CROSS SECTIONS (BARNS)

AND ESTIMATED DISADVANTAGE FACTORS (DF)

\begin{tabular}{|c|c|c|c|c|c|c|}
\hline \multirow[b]{2}{*}{ Element } & \multicolumn{2}{|c|}{ Cold } & \multicolumn{2}{|c|}{ Hot, $V=0$} & \multicolumn{2}{|c|}{ Hot, $V=0.4$} \\
\hline & $\sigma_{\mathbf{a}}$ & $\sigma_{t r}$ & $\sigma_{\mathrm{a}}$ & $\sigma_{\mathrm{tr}}$ & $\sigma_{\mathrm{a}}$ & $\sigma_{t r}$ \\
\hline $\mathrm{H}$ & 0.2168 & 26.06 & 0.1790 & 21.45 & 0.1651 & $19.6 \%$ \\
\hline 0 & 0 & 4.02 & 0 & 4.02 & 0 & 4.02 \\
\hline $\mathrm{Zr}$ & 0.1176 & 8.0 & 0.09708 & 8.0 & 0.08950 & 8.0 \\
\hline $\mathrm{A} 1$ & 0.1502 & 1.37 & 0.1240 & 1.37 & 0.1143 & 1.37 \\
\hline $\mathrm{U}^{235} \sigma_{\mathrm{a}}$ & 428.0 & 10.0 & 341.9 & 10.0 & 312.4 & 10.0 \\
\hline$\sigma_{f}$ & 360.7 & & 288.1 & & 263.0 & \\
\hline $\mathrm{U}^{238}$ & 1.783 & 10.0 & 1.472 & 10.0 & 1.357 & 10.0 \\
\hline Unit A & 0.6531 & 0 & 0.5393 & 0 & 0.4972 & 0 \\
\hline $\begin{array}{c}\text { Disadvantage } \\
\text { Factors: }\end{array}$ & Co & & Hot, V & $=0$ & Hot, V & 0.4 \\
\hline $\bar{\phi} \bmod / \bar{\phi}$ fuel & 1.1 & & 1.1 & & 1. & \\
\hline DF, fuel & 0. & 385 & 0.9 & & & 174 \\
\hline$D F, \bmod$ & 1.0 & 793 & 1.0 & & & 37 \\
\hline
\end{tabular}


The cross sections for materials other than fuel (specifically, core and reflector water, zirconium rod followers, control rods, and spacers) have been taken from Ref. 2, Section 4.

Macroscopic cross-section sets

Hot operating cross sections (Univac Cross-Section Set 163) based on the "large" cell (Class A) are given in Table 10; Class B cross sections for the "small" cell (evaluated for cold conditions) are given in Table ll.

The values of $\nu \Sigma_{f}$ in the Class A cross sections are divided by 1.05 to allow for xenon, samarium, and error.

Check on calculation

A check on the Class B cross sections was afforded by using the techniques just described to calculate equivalent homogeneous cross sections for a lattice described by MacKinney and Ball (Ref. 7). This lattice was similar in many respects to the lattices considered here. Using an estimated ratio of average flux in the moderator to average flux in the fuel of 1.15 and calculating the Dancoff correction factor for nearest neighbor and next nearest neighbors, we found that $\mathrm{k}_{\mathrm{eff}}=0.98$ for a lattice reported to have $k_{\text {eff }}=1.0$. Errors in interpretation of the reported data or in the value of reflector savings (estimated at $7.3 \mathrm{~cm}$ ) can easily explain the discrepancy in $k_{\text {eff }}$. 
Table 10

UNIVAC CROSS-SECTION SET 163

\begin{tabular}{|c|c|c|c|c|c|c|c|c|c|}
\hline \multicolumn{2}{|c|}{$\underbrace{\text { Material no. }}_{\text {Group }}$} & $\begin{array}{c}1 \\
\text { Base Element } \\
\left(\text { no } \mathrm{U}^{233}\right), 0 \mathrm{~V}\end{array}$ & $\begin{array}{c}2 \\
\text { Base Element } \\
\left(\text { no } \mathrm{U}^{235}\right), 4 \mathrm{~V} \\
\end{array}$ & $\mathrm{U}^{235}$ & $\mathrm{Pu}^{239}$ & $\mathrm{Pu}^{240}$ & $\mathrm{Pu}^{241}$ & \begin{tabular}{l}
\multicolumn{1}{c}{7} \\
Reflector \\
Water \\
\end{tabular} & $\begin{array}{c}8 \\
" 1 / v " \\
\text { absorber }\end{array}$ \\
\hline 1) & $\begin{array}{l}\Sigma_{1 \rightarrow 2} \\
3 \Sigma_{\mathrm{tr}}\end{array}$ & $\begin{array}{r}\text { PR0B. } 163000 \\
0000032750 n 0 \\
0000623790 n 0 \\
00000006000 r \\
000003275600 \\
000068929000\end{array}$ & $\begin{array}{l}0000000000000 \\
000002177000 \\
000052705000 \\
000000000000 \\
000002177000 \\
000057059000\end{array}$ & $\begin{array}{l}0000000000000 \\
0000000000000 \\
000000000000 \\
000000000000 \\
0000000000000 \\
0000000000000\end{array}$ & 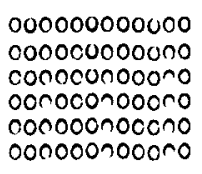 & $\begin{array}{l}000000000000 \\
000000000000 \\
000000000000 \\
000000000000 \\
000000000000 \\
000000000000\end{array}$ & $\begin{array}{l}000000000000 \\
000000000000 \\
000000000000 \\
000000000000 \\
000000000000 \\
0000000000000\end{array}$ & $\begin{array}{l}000000000000 \\
000005117 c 00 \\
000048379000 \\
000000000600 \\
000005117600 \\
000058613000\end{array}$ & $\begin{array}{l}0000000000000 \\
000000000000 \\
000000000000 \\
000000,000000 \\
000000000000 \\
000000000000\end{array}$ \\
\hline & $\begin{array}{l}3 \Sigma_{\operatorname{tr}} \\
\nu \Sigma_{f}\end{array}$ & $\begin{array}{l}\text { 0002505380no } \\
0000000000 n n \\
0000000000 r n \\
0002520510 n d \\
0000000000 n \\
0000000000 n n\end{array}$ & $\begin{array}{l}000162720000 \\
000000000000 \\
000000000000 \\
000163922000 \\
000000000000 \\
000000000000\end{array}$ & $\begin{array}{l}0000000000000 \\
000034050000 \\
000000000000 \\
000050491000 \\
000000000000 \\
0000000000000\end{array}$ & 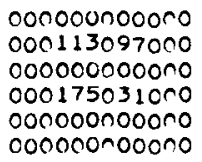 & $\begin{array}{l}000000000000 \\
0,0000000000 \\
0 \cap 0000000000 \\
0,0005425000 \\
000000000000 \\
0,0000000000\end{array}$ & $\begin{array}{l}000000000000 \\
000077959000 \\
000000000000 \\
000114305000 \\
000000000000 \\
000000000000\end{array}$ & $\begin{array}{l}00034129 c 000 \\
00000000 c 000 \\
00000000 C 000 \\
000342428 C 00 \\
00000000 C 600 \\
000000000600\end{array}$ & $\begin{array}{l}1000000000000 \\
000000000000 \\
000000000000 \\
000016441000 \\
000000000000 \\
000000000000\end{array}$ \\
\hline
\end{tabular}

All cross sections are in units of $\mathrm{cm}^{-1}$ Fission neutrons are born in group I Decimal point is between 4 th and 5 th figures in all of above numbers

Cross Section Set 163 Class A cross sections for hot operating core Material list and volume fraction formulae

Material

1
2
3
4
5
6
7
8

\begin{tabular}{l} 
Identification \\
\hline Base element $\left(\mathrm{no} \mathrm{U}^{235}\right), \mathrm{V}=0$ \\
Base element $\left(\right.$ no $\left.\mathrm{U}^{235}\right), \mathrm{V}=04$ \\
$\mathrm{U}^{235}$ \\
$\mathrm{Pu}^{239}$ \\
$\mathrm{Pu}^{240}$ \\
$\mathrm{Pu}^{241}$ \\
$\mathrm{Reflector}^{20}$ Water \\
"l/v" absorber
\end{tabular}

\begin{tabular}{l} 
Volume Fraction \\
\hline $1-(\mathrm{V} / 04)$ \\
$\mathrm{V} / 04$ \\
$\mathrm{~N} / 0000531 \quad($ see Note 1$)$ \\
$\mathrm{N} / 0000531$ \\
$\mathrm{~N} / 0000531$ \\
$\mathrm{~N} / 0000531$ \\
$\mathrm{~L}-(\mathrm{V} / 04)$ \\
$\Sigma_{\text {a3 }}($ Mat'l 8$)-\Sigma_{\mathrm{a3}}\left(\mathrm{U}^{235}\right)$ \\
To represent the fission products from the fission of \\
$\mathrm{B}$ atoms per original U atom, VF (Mat'1 8$)=0$ 6944 B
\end{tabular}

Note $1 \mathrm{~N}$ is the number of atoms per $\mathrm{cm}^{3}$ of reactor core At $\mathrm{N} / 0000531=1$ the enrichment $1 \mathrm{~s}$ ten times natural Cross sections of materials $3,4,5,6$ are evaluated at $25 \%$ mean vord 
Table 11

MACROSCOPIC CROSS-SECTION SET PDQ-3

(Cold set for control rod studies)

\begin{tabular}{|c|c|c|c|c|c|c|}
\hline Group & Comp & $\mathrm{D}$ & $\Sigma_{c}+\Sigma_{f}$ & $\Sigma_{j \rightarrow j+1}$ & $\nu \Sigma_{\mathrm{f}}$ & $\begin{array}{l}\text { Fission } \\
\text { Neutron } \\
\text { Spectrum }\end{array}$ \\
\hline 1 & 1 & 1.650160 & 0.000000 & 0.068760 & 0.000000 & 1.000000 \\
\hline 1 & 2 & 1.465328 & 0.000000 & 0.039735 & 0.000000 & 1.000000 \\
\hline 1 & 3 & 1.465328 & 0.000000 & 0.039735 & 0.000000 & 1.000000 \\
\hline 1 & 4 & 1.465328 & 0.000000 & 0.039735 & 0.000000 & 1.000000 \\
\hline 1 & 5 & 1.426880 & 0.000000 & 0.038340 & 0.000000 & 1.000000 \\
\hline 1 & 6 & 1.353580 & 0.000000 & 0.011860 & 0.000000 & 1.000000 \\
\hline 1 & 7 & 1.256820 & 0.000000 & 0.007920 & 0.000000 & 1.000000 \\
\hline 1 & 8 & 1.650160 & 0.000000 & 0.068760 & 0.000000 & 1.000000 \\
\hline 2 & 1 & 0.605240 & 0.000360 & 0.083250 & 0.000000 & 0.000000 \\
\hline 2 & 2 & 0.751291 & 0.017080 & 0.042140 & 0.010532 & 0.000000 \\
\hline 2 & 3 & 0.751291 & 0.015620 & 0.042140 & 0.008426 & 0.000000 \\
\hline 2 & 4 & 0.751291 & 0.018495 & 0.042140 & 0.012638 & 0.000000 \\
\hline 2 & 5 & 0.784100 & 0.000300 & 0.041922 & 0.000000 & 0.000000 \\
\hline 2 & 6 & 0.388050 & 0.089290 & 0.000000 & 0.000000 & 0.000000 \\
\hline 2 & 7 & 1.113040 & 0.000250 & 0.000594 & 0.000000 & 0.000000 \\
\hline 2 & 8 & 0.605240 & 0.000360 & 0.083250 & 0.000000 & 0.000000 \\
\hline 3 & 1 & 0.159600 & 0.016200 & & 0.000000 & 0.000000 \\
\hline 3 & 2 & 0.281686 & 0.125439 & & 0.191582 & 0.000000 \\
\hline 3 & 3 & 0.281686 & 0.104085 & & 0.153265 & 0.000000 \\
\hline 3 & 4 & 0.281686 & 0.145920 & & 0.229890 & 0.000000 \\
\hline 3 & 5 & 0.284610 & 0.010960 & & 0.000000 & 0.000000 \\
\hline 3 & 6 & 0.000000 & 0.469480 & & 0.000000 & 0.000000 \\
\hline 3 & 7 & 1.313370 & 0.005710 & & 0.000000 & 0.000000 \\
\hline 3 & 8 & 0.134620 & 0.019360 & & 0.000000 & 0.000000 \\
\hline
\end{tabular}

Composition Identification List

1. Core water

2. $3 \%$ enrichment elements

3. $2.4 \%$ enrichment elements

4. $3.6 \%$ enrichment elements
5. Spacer

6. Control rod

7. $\mathrm{Zr}$ follower

8. Reflector water 


\section{AUXILIARY TABLES FOR AVERAGE AND REJECT BLANKET COMPOSITION}

The tables given in this section facilitate the evaluation of the blanket isotopic composition for various conditions of initial enrichment and initial conversion ratio. From them, values may be easily obtained for both the reject and average composition for various burnups.

A. Final and Average Isotopic Compositions under Linear Irradiation

Table 12 relates the buildup of the various plutonium isotopes to the burnup of the initially present $U^{235}$. The table is quite general and applicable to any thermal system; the results are dependent only on ratios of microscopic cross sections and thus, to a first approximation, independent of the details of the reactor.

Table 12

FINAL AND AVERAGE (FOR LINEAR IRRADIATION) ISOTOPIC COMPOSITIONS

for $I C R=1$

\begin{tabular}{|c|c|c|c|c|c|c|c|c|c|c|c|}
\hline & $\mathrm{b}$ & $\mathrm{n}_{25}$ & $\overline{\mathrm{n}}_{25}$ & $n_{49}$ & $n_{40}$ & $\mathrm{n}_{41}$ & $f_{p}$ & $\bar{n}_{49}$ & $\overline{\mathrm{n}}_{40}$ & $\overline{\mathrm{n}}_{41}$ & $\bar{f}_{\mathrm{p}}$ \\
\hline 0 & 0 & 1 & 0 & 0 & 0 & 0 & 0 & 0 & 0 & 0 & 0 \\
\hline 01 & 00952 & 09048 & 09516 & 0087 & 0005 & 00002 & 0008 & 0043 & 0003 & 00001 & 004 \\
\hline 2 & 1813 & 08187 & 09064 & 0154 & 0019 & & 0030 & 0081 & 008 & 00004 & 0115 \\
\hline 3 & 02592 & 0740 & 086 & 0204 & 0034 & 000 & 0060 & 114 & 014 & 0010 & 0227 \\
\hline 4 & 3297 & 067 & 242 & 242 & 0052 & 00065 & 0102 & 141 & 021 & & 0372 \\
\hline 5 & 03935 & 060 & 07869 & 0271 & 0072 & 00098 & 0144 & 164 & 029 & & 0544 \\
\hline 06 & 04512 & 05488 & 07520 & 0292 & 00 & & & $\begin{array}{lll}0 & 184\end{array}$ & & & 0732 \\
\hline 7 & 050 & 04 & & 03 & 01 & & & 2 & & & 0939 \\
\hline 8 & 05507 & 044 & 068 & 320 & 013 & 00266 & 030 & 215 & 0 & & 1165 \\
\hline 9 & 05934 & 040 & 06594 & 0329 & 0154 & 00337 & 03 & 227 & & & 1411 \\
\hline 0 & 06321 & 036 & & 03 & 01 & & & 37 & & & \\
\hline 1 & 06671 & 03 & 06 & 34 & 01 & $\begin{array}{lll}0 & 04\end{array}$ & 0508 & 24 & 00 & 0 & 1951 \\
\hline 2 & 06988 & & & 34 & 02 & 00 & 0578 & 0255 & 00 & & 2241 \\
\hline 3 & 07275 & 0272 & & 0349 & 02 & & & 0262 & 01 & $\begin{array}{lll}0 & 02\end{array}$ & 2542 \\
\hline 4 & 075 & 02 & & 3 & 02 & & & 02 & & & \\
\hline 5 & 07 & 022 & 051 & 035 & 025 & 00773 & 0795 & 274 & 01 & 0 & 3170 \\
\hline 6 & & & & 035 & 02 & 008 & 0870 & 79 & & 2 & 3492 \\
\hline 7 & 08173 & 018 & & 035 & 02 & 009 & 0950 & 02 & & 0 & 3822 \\
\hline 8 & 083 & & & 03 & 02 & & 10 & & & & \\
\hline 9 & 85 & & & 3 & & & 11 & 2 & & & \\
\hline 20 & 086 & & & 03 & 03 & & 1185 & 94 & & 0 & 4852 \\
\hline 21 & 08775 & 012 & 041 & 035 & 03 & & 12 & $\begin{array}{ll}0297 \\
\end{array}$ & & & 05204 \\
\hline 2 & 0889 & & & 03 & & & & & & & \\
\hline & & & & & & & & & & & \\
\hline & & & & & & & & & & & \\
\hline & 9179 & 00821 & 03672 & 0357 & 0342 & 01288 & 1528 & $\begin{array}{lll}0 & 307\end{array}$ & 0188 & 00585 & 6611 \\
\hline
\end{tabular}

The basic data used to generate Table 12 were obtained from Spinrad et al. (Ref. 8). The results in that report were obtained with the aid of the following assumption It was assumed that the sum of both resonance and thermal absorption in $\mathrm{U}^{238}$ can be characterized by a single 
effective $\mathrm{U}^{238}$ capture cross section that is constant in time. This assumption is strictly valid only if the thermal blackness, i.e., the macroscopic thermal absorption cross section, does not vary with time, since otherwise the relative amounts of resonance and thermal capture will also vary with time and thus not permit capture in $\mathrm{U}^{238}$ to be characterized by a single parameter. The validity of the numbers in Table 12 is thus also dependent on the validity of this approximation. The advantage that results from the use of this approximation is that all plutonium isotope densities at a given value of the flux-time are then proportional, in systems otherwise identical, to the initial conversion ratio (ICR).

The isotopic density data in Table III of Ref. 8 for various ICR were converted to unit ICR. Since all plutonium isotopic densities are proportional to ICR, this was accomplished by dividing the values for the plutonium isotopes by the corresponding value of ICR.

The data in Table 12 are presented with $t$ as the independent variable, and the fractional los in $\mathrm{U}^{235}, \mathrm{~b}$, is given by

$$
\mathrm{b} \equiv\left(\mathrm{n}_{0}^{25}-\mathrm{n}^{25}\right) / \mathrm{n}_{0}^{25}=1-\mathrm{e}^{-\mathrm{t}} .
$$

The variable $t$ is proportional to the time for the case of constant flux and in all cases is proportional to the flux-time. The plutonium isotope densities, $\mathrm{n}^{\mathrm{i}}$, in Table 12 are given in terms of atoms of plutonium per original atom of $\mathrm{U}^{235}$. With the as sumption of a single effective $\mathrm{U}^{238}$ capture cross section, the plutonium isotope densities at any given value of the flux-time are all proportional to the ICR. The values given in Table 12 are for $\mathrm{ICR}=1$. The corresponding values of the plutonium isotope for any other value of ICR can be obtained simply by multiplying the values given in Table 12 by the value of the ICR. In addition to the values of the plutonium isotope densities, the number of plutonium fissions in $\mathrm{Pu}^{239}$ and $\mathrm{Pu}^{24 \mathrm{I}}$, namely $f_{p}$, that have occurred are given.

The values of $\mathrm{n}^{i}$ and $f_{\mathrm{p}}$ in Table 12 all refer to those that exist at a particular time in the history of the irradiation of a sample consisting initially of a mixture of $\mathrm{U}^{235}$ and $\mathrm{U}^{238}$ only. In addition, it is of interest to have the average values from the start of the irradiation to the time in question. The averages we seek are with respect to the flux-time (or with respect to $t$, since the two are proportional). The average values $\bar{n}^{i}$ and $\overline{f_{p}}$ are also given in Table 12 . The same proportionality to ICR of course also exists for the average plutonium quantities.

B. Final and Average Values of Isotopic Composition for the Systems Studied in This Report

Table 13 pertains more specifically to the systems under study in this report. For each initial enrichment selected, the ICR has been 
evaluated by use of the formula

$$
\mathrm{ICR}=\frac{\mathrm{U}_{0}^{28} \sigma_{c}^{28}}{\mathrm{U}_{0}^{25} \sigma_{\mathrm{a}}^{25}}+\frac{\sum_{\mathrm{a}}^{\mathrm{tot}}\left(1+\mathrm{L}^{2} \mathrm{~B}^{2}\right)(1-\mathrm{p})}{\mathrm{U}_{0}^{25} \sigma_{\mathrm{a}}^{25} \mathrm{p}},
$$

where $\mathrm{U}_{0}^{25}$ and $\mathrm{U}_{0}^{28}$ are the initial atom densities of $\mathrm{U}^{235}$ and $\mathrm{U}^{238}$, respectively. The rest of the notation is standard; the cross sections and $L^{2}$ all refer to thermal energy. Using the values:

\begin{tabular}{|c|c|c|}
\hline & 0 void & 0.6 void \\
\hline$\sigma_{c}^{28}$ (barns) & 1.663 & 1.526 \\
\hline$\sigma_{\mathrm{a}}^{25}$ (barns) & 391.2 & 356 \\
\hline$\sum_{\mathrm{a}}^{\mathrm{tot}}$, no $25\left(\mathrm{~cm}^{-1}\right)$ & 0.02138 & 0.01559 \\
\hline$\Sigma_{\mathrm{tr}}\left(\mathrm{cm}^{-1}\right)$ & 0.858 & 0.410 \\
\hline $\mathrm{B}^{2}\left(\mathrm{~cm}^{-2}\right)$ & 0.001 & \\
\hline $\begin{array}{l}\text { Initial } \mathrm{U} \text { atom } \\
\text { density }\left(\mathrm{cm}^{-3}\right)\end{array}$ & \multicolumn{2}{|c|}{$0.00479 \times 10^{24}$} \\
\hline p (operating) & \multicolumn{2}{|l|}{0.8} \\
\hline
\end{tabular}

we obtain the following values of ICR for various enrichments $E_{0}=U_{0}^{25} /$ $\left(\mathrm{U}_{0}^{25}+\mathrm{U}_{0}^{28}\right)$ :

\begin{tabular}{|c|c|c|c|}
\hline $\mathrm{E}_{0}$ & ICR & $\mathrm{E}_{0}$ & ICR \\
\hline 0.0072 & 1.223 & 0.02 & 0.5975 \\
\hline 0.01 & 0.9490 & 0.03 & 0.4802 \\
\hline 0.015 & 0.7145 & 0.04 & 0.4216 \\
\hline
\end{tabular}

We obtain the values for the various isotopic compositions by first finding the values of $t$ for which

$$
\left(\frac{b}{1+\alpha_{25}}+\operatorname{ICR} f_{p}\right) E_{0}=B \text {, }
$$

where $B$ is the desired reject fission burnup, fissions per original uranium atom, and $\alpha_{25}$ is the capture-to-fission ratio of $\mathrm{U}^{235}$. Using Table 12 for these values of $t$, we obtain the values given in Table 13 . Numerically this is achieved by multiplying the entries in Table 12 by $E_{0} \times$ ICR in the case of the plutonium isotopes, and by $E_{0}$ for $U^{235}$.

All of the atomic densities given in Table 13 are given per original uranium atom. 
FINAL AND AVERAGE (FOR LINEAR IRRADIATION) BLANKET COMPOSITIONS

FOR VARIOUS BLANKET ENRICHMENTS AND BURNUPS OF CURRENT STUDY

\begin{tabular}{|c|c|c|c|c|c|c|c|c|c|c|c|}
\hline$E_{0}$ & B & ICR & $\mathbf{t}$ & $\mathrm{N}_{25}$ & $\overline{\mathbf{N}}_{25}$ & $\mathrm{~N}_{49}$ & $\mathrm{~N}_{40}$ & $N_{41}$ & $\bar{N}_{49}$ & $\overline{\mathbf{N}}_{40}$ & $\bar{N}_{41}$ \\
\hline \multirow[t]{4}{*}{0.0072} & 0.0025 & 1.223 & 0.38 & 0.00493 & 0.00597 & 0.00207 & 0.00043 & 0.00005 & 0.00119 & 0.00017 & 0.00001 \\
\hline & 0.005 & & 0.645 & 0.00379 & 0.00529 & 0.00263 & 0.00090 & 0.00016 & 0.00168 & 0.00037 & 0.00005 \\
\hline & 0.0075 & & 0.970 & 0.00274 & 0.00460 & 0.00294 & 0.00147 & 0.00035 & 0.00206 & 0.00065 & 0.00012 \\
\hline & 0.01 & & 3.300 & 0.00197 & 0.00403 & 0.00306 & 0.00196 & 0.00099 & 0.00230 & 0.00092 & 0.00020 \\
\hline \multirow[t]{4}{*}{0.01} & 0.0025 & 0.9490 & 0.26 & 0.00771 & 0.00880 & 0.00178 & 0.00026 & 0.00002 & 0.00096 & 0.00010 & 0.00001 \\
\hline & 0.005 & & 0.525 & 0.00592 & 0.00777 & 0.00262 & 0.00073 & 0.00010 & 0.00160 & 0.00030 & 0.00003 \\
\hline & 0.0075 & & 0.784 & 0.00457 & 0.00692 & 0.00302 & 0.00125 & 0.00025 & 0.00201 & 0.00053 & 0.00008 \\
\hline & 0.01 & & 1.045 & 0.00352 & 0.00620 & 0.00321 & 0.00172 & 0.00043 & 0.00229 & 0.00076 & 0.00014 \\
\hline \multirow[t]{7}{*}{0.015} & 0.0025 & 0.7145 & 0.190 & 0.01243 & 0.01353 & 0.00156 & 0.00018 & 0.00001 & 0.00082 & 0.00008 & 0.000004 \\
\hline & 0.005 & & 0.378 & 0.01030 & 0.01244 & 0.00249 & 0.00051 & 0.00006 & 0.00144 & 0.00021 & 0.00002 \\
\hline & 0.0075 & & 0.570 & 0.00849 & 0.01141 & 0.00306 & 0.00093 & 0.00014 & 0.00190 & 0.00038 & 0.00004 \\
\hline & 0.01 & & 0.766 & 0.00699 & 0.01046 & 0.00338 & 0.00137 & 0.00027 & 0.00224 & 0.00058 & 0.00008 \\
\hline & 0.015 & & 1.193 & 0.00456 & 0.00875 & 0.00516 & 0.00309 & 0.00083 & 0.00381 & 0.00142 & 0.00029 \\
\hline & 0.02 & & 1.65 & 0.00288 & 0.00734 & 0.00531 & 0.00404 & 0.00131 & 0.00421 & 0.00202 & 0.00051 \\
\hline & 0.025 & & 2.127 & 0.00178 & 0.00621 & 0.00536 & 0.00470 & 0.00170 & 0.00446 & 0.00255 & 0.00073 \\
\hline \multirow[t]{7}{*}{0.02} & 0.0025 & 0.5975 & 0.145 & 0.01731 & 0.01855 & 0.00142 & 0.00012 & 0.00001 & 0.00071 & 0.00006 & 0.000002 \\
\hline & 0.005 & & 0.292 & 0.01496 & 0.01726 & 0.00240 & 0.00039 & 0.00003 & 0.00132 & 0.00016 & 0.00001 \\
\hline & 0.0075 & & 0.442 & 0.01288 & 0.01611 & 0.00303 & 0.00072 & 0.00009 & 0.00180 & 0.00029 & 0.00003 \\
\hline & 0.01 & & 0.596 & 0.01104 & 0.01503 & 0.00347 & 0.00110 & 0.00018 & 0.00218 & 0.00045 & 0.00005 \\
\hline & 0.015 & & 0.93 & 0.00790 & 0.01300 & 0.00396 & 0.00191 & 0.00044 & 0.00274 & 0.00083 & 0.00014 \\
\hline & 0.02 & & 1. 294 & 0.00550 & 0.01121 & 0.00415 & 0.00265 & 0.00075 & 0.00312 & 0.00124 & 0.00027 \\
\hline & 0.025 & & 1.682 & 0.00373 & 0.00967 & 0.00423 & 0.00326 & 0.00107 & 0.00337 & 0.00164 & 0.00042 \\
\hline \multirow[t]{5}{*}{0.03} & 0.005 & 0.4802 & 0.193 & 0.02476 & 0.02714 & 0.00212 & 0.00025 & 0.00002 & 0.00111 & 0.00011 & 0.00001 \\
\hline & 0.01 & & 0.402 & 0.02008 & 0.02468 & 0.00348 & 0.00075 & 0.00008 & 0.00204 & 0.00030 & 0.00003 \\
\hline & 0.015 & & 0.625 & 0.01609 & 0.02225 & 0.00425 & 0.00142 & 0.00036 & 0.00270 & 0.00058 & 0.00007 \\
\hline & 0.02 & & 0.870 & 0.01260 & 0.02000 & 0.00470 & 0.00214 & 0.00046 & 0.00321 & 0.00092 & 0.00015 \\
\hline & 0.025 & & 1.143 & 0.00959 & 0.01786 & 0.00494 & 0.00285 & 0.00075 & 0.00360 & 0.00130 & 0.00026 \\
\hline \multirow[t]{5}{*}{0.04} & 0.005 & 0.4216 & 0.15 & 0.03446 & 0.03696 & 0.00205 & 0.00018 & 0.00001 & 0.00104 & 0.00009 & 0.000004 \\
\hline & 0.015 & & 0.30 & 0.02969 & 0.03437 & 0.00343 & 0.00058 & 0.00005 & 0.00190 & 0.00023 & 0.00002 \\
\hline & 0.015 & & 0.466 & 0.02516 & 0.03186 & 0.00438 & 0.00110 & 0.00014 & 0.00263 & 0.00044 & 0.00004 \\
\hline & 0.02 & & 0.644 & 0.02104 & 0.02944 & 0.00504 & 0.00173 & 0.00030 & 0.00321 & 0.00071 & 0.00009 \\
\hline & $.0 \geq 5$ & & 0.840 & 0.01729 & 0.02303 & 0.00546 & 0.00240 & 0.00050 & 0.00370 & 0.00103 & 0.00016 \\
\hline
\end{tabular}


C. Error Introduced by the Assumption of Constant Thermal Blackness

The validity of the results obtained so far in this section depends on the validity of the approximation inherent in the implicit use of an effective capture cross section for $U^{238}$, i.e., they depend on the validity of the assumption that the thermal blackness does not vary appreciably with irradiation. The following considerations will indicate that the error introduced by the variation of blackness is not in fact important for the systems considered in this report. Therefore, the results reported in subsequent sections are based on the discussion in Sections A and B, without any corrections for the errors discussed in this section. Taking these errors into account would not substantially change the conclusions.

The error introduced by the approximation is negligible if the change in blackness with irradiation is negligible. One case in which we can validly assume that the re is no change in blackness is the equilibrium case of uniformly mixed material of all stages of irradiation from zero to the reject burnup; we further assume that the individual elements are sufficiently small that there are no self-shielding effects. While an element is undergoing its full irradiation from insertion to discharge, it is immersed the entire time in the medium of average composition. The average composition of this medium is, of course, related to the average composition of the element during its life cycle and is in fact equal to the time-averaged composition.

We now consider the problem of determining the plutonium isotope concentration as a function of ir radiation in this system. In this case the approximation in using an effective $\mathrm{U}^{238}$ capture cross section introduces no error providing that we specify the ICR as the value that exists in a small sample of fresh uranium when it is embedded in a medium of the equilibrium average composition. The blackness that will determine the relative amounts of thermal and epithermal capture is that of the average medium and is not at all dependent on the fresh sample blackness.

We might expect it not to be straightforward to solve for the ICR, since it depends on the average composition of the medium and the average composition, in turn, depends on the ICR. It turns out, however, that because the expression for the ICR is linear in the unknown microscopic absorption cross sections of the plutonium isotopes and because the plutonium isotope concentrations are directly proportional to the ICR, that we can solve directly and explicitly for the ICR. Equation (2) is still valid, provided we take for $\Sigma_{a}^{\text {tot }}$ and $L^{2}$ the equilibrium values of these quantities. 
We obtain

$\operatorname{ICR}(\mathrm{b})=\frac{\frac{\mathrm{U}_{\mathrm{a}}^{28} \sigma_{\mathrm{a}}^{28}}{\mathrm{U}_{0}^{25} \sigma_{\mathrm{a}}^{25}}+\frac{1-\mathrm{p}}{\mathrm{p}}\left[\frac{\mathrm{U}_{0}^{28} \sigma_{\mathrm{a}}^{28}}{\mathrm{U}_{0}^{25} \sigma_{\mathrm{a}}^{25}}+\overline{\mathrm{n}}_{25}(\mathrm{~b})+\frac{\sum_{\mathrm{a}}^{\mathrm{P}}+\mathrm{DB}^{2}}{\mathrm{U}_{0}^{25} \sigma_{\mathrm{a}}^{25}}+\frac{1-\overline{\mathrm{n}}_{25}(\mathrm{~b})}{1+\alpha^{25}} \frac{\sigma_{\mathrm{a}}^{\mathrm{FP}}}{\sigma_{\mathrm{a}}^{25}}\right]}{\mathrm{I}-\frac{1-\mathrm{p}}{\mathrm{p}}\left[\frac{\sigma_{\mathrm{a}}^{49}}{\sigma_{\mathrm{a}}^{25}} \overline{\mathrm{n}}_{49}(\mathrm{~b})+\frac{\sigma_{\mathrm{a}}^{40}}{\sigma_{\mathrm{a}}^{25}} \overline{\mathrm{n}}_{40}(\mathrm{~b})+\frac{\sigma_{\mathrm{a}}^{41}}{\sigma_{\mathrm{a}}^{25}} \overline{\mathrm{n}}_{41}(\mathrm{~b})+\frac{\sigma_{\mathrm{a}}^{\mathrm{FP}}}{\sigma_{\mathrm{a}}^{25}} \overline{\mathrm{f}}_{\mathrm{P}}(\mathrm{b})\right]}$,

where $\sum \underset{\mathrm{a}}{\mathrm{P}}$ is the microscopic parasitic thermal absorption cross section excluding fission products, $\mathrm{DB}^{2}$ is the microscopic thermal "leakage" cross section, $\sigma \mathrm{FP}$ is the microscopic thermal absorption cross section of a fission product pair, and $\sigma \frac{i}{a}$ is the microscopic the rmal absorption cross section of the $i^{\prime}$ th isotope. The relationships between $t, b$, and $B$ are given in Eqs. (1) and (3).

The results corresponding to Table 13 but using the equilibrium thermal blackness to determine the ICR are given in Table 14 It may be seen that the differences are not appreciable, and we conclude that the simpler analysis using Table 13 will not introduce appreciable error.

Table 14

FINAL AND AVERAGE (FOR LINEAR IRRADIATION) BLANKET COMPOSITIONS FOR VARIOUS BLANKET ENRICHMENTS AND BURNUPS OF CURRENT STUDY (EQUILIBRI UM THERMAL BLACKNESS)

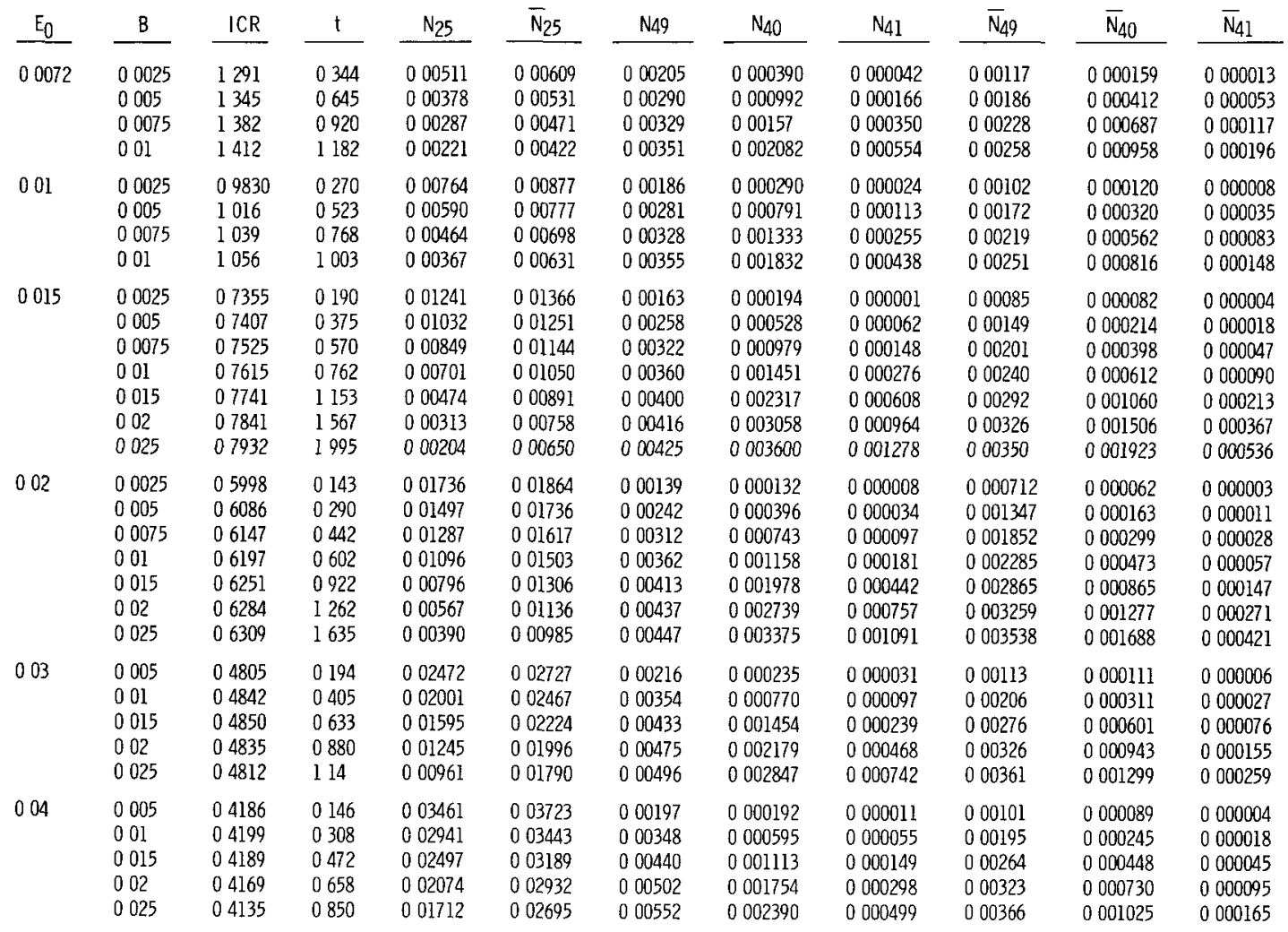




\section{STUDY OF SPIKED PLUTONIUM RECYCLE SYSTEMS}

The study is based on a parametric survey consisting of a number of cases. Both large (full-scale power plants) and small (EBWR)-sized $\mathrm{Pu}^{239}$-spiked systems and also small $\mathrm{U}^{235}$-spiked systems were considered. Except for dimensions, the basic geometry was identical in all the cases; it consisted of the following radial regions in cylindrical geometry:

$\begin{array}{rlr}\text { I Central Blanket } & \text { Assumed Void }=0.2 \\ \text { II Spiked Region } & \text { Assumed Void }=0.4 \\ \text { III Outer Blanket } & \text { Assumed Void }=0.15 \\ \text { IV Water Reflector } & \end{array}$

The assumed voids are appropriate for systems having power densities approximately that of EBWR when it is operating at a total power of $100 \mathrm{Mw}$.

Except for the differences in assumed void the compositions of the central and outer blankets are identical.

The calculations were performed utilizing cylindrical one-dimensional diffusion theory with an equivalent bare core height. Table 15 summarizes the results of this phase of the study. The last few columns in Table 15 are obtained in the following manner. We have

$\frac{\text { Atoms }\left\{\begin{array}{l}49 \\ 25\end{array}\right\} \text { burned in spike }}{\text { Fissions in reactor }}=\frac{\text { Fissions in spike }}{\text { Fissions in reactor }} \times \frac{\text { Atoms }\left\{\begin{array}{l}49 \\ 25\end{array}\right\} \text { burned in spike }}{\text { Fissions in spike }}$

$$
=P_{S}\left\{\begin{array}{l}
1+\alpha^{49} \\
1+\alpha^{25}
\end{array}\right\}=P_{S}\left\{\begin{array}{l}
1.619 \\
1.183
\end{array}\right\}
$$

where $P_{S}$ is the fraction of the total power developed in the spiked region. We also have

$\frac{\text { Atoms }(49+41) \text { removed from blanket }}{\text { Fissions in reactor }}=\frac{\text { Atoms } \frac{49+41}{U_{0}} \text { in reject material }}{\frac{\text { Fissions in blanket }}{U_{0}}} \times$

$$
\frac{\text { Fissions in blanket }}{\text { Fissions in reactor }}=\frac{\mathrm{N}_{49}+\mathrm{N}_{41}}{\mathrm{~B}} \times\left(1-\mathrm{P}_{\mathrm{S}}\right) \text {. }
$$

At $\mathrm{t}=0$, the last expression is indeterminate, but may be obtained from

$\frac{\text { Atoms }(49+41) \text { removed from blanket }}{\text { Fissions in reactor }} \quad \begin{aligned}=(\text { ICR }) \text { blanket }\left(1+\alpha^{25}\right)\left(1-P_{S}\right) \\ \lim t=0\end{aligned}$

The production ratio, $P R$, is defined as the ratio

Atoms $(49+41)$ removed from the blanket

Atoms $\{49\}$ burned in spike 
Table 15

SUMMARY OF RESULTS OBT AINED IN STUDY OF SPIKED SYSTEM

\begin{tabular}{|c|c|c|c|c|c|c|c|c|c|c|c|c|c|c|c|}
\hline & Case No. & $\begin{array}{l}\text { Intitial } \\
\text { Blanket } \\
\text { Enrichment, } \\
E_{0}\end{array}$ & 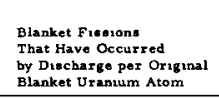 & $\begin{array}{l}\text { Outer Radius } \\
\text { of Spike } \\
\text { Reglon, em }\end{array}$ & $\begin{array}{l}\longleftarrow \text { Atome Uass per } \\
\text { Orginal Blanket } \\
\text { Urantum Atom }\end{array}$ & 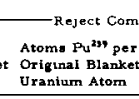 & 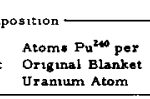 & 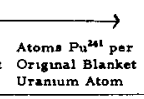 & $\begin{array}{l}\text { Critical } \\
\text { Loading of } \\
\text { Spplee }\end{array}$ & $\begin{array}{l}\text { Fraction of } \\
\text { Totat Powar } \\
\text { Developed un } \\
\text { Sppike Reg ion } \\
\end{array}$ & 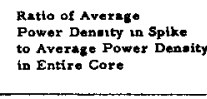 & 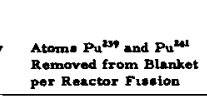 & 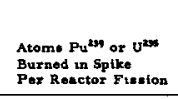 & 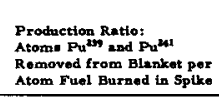 & Ca.e. No. \\
\hline \multirow{22}{*}{ 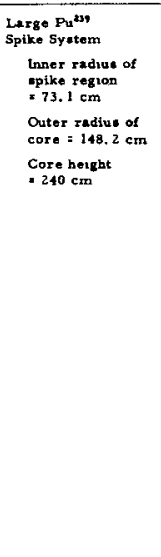 } & 1 & 0.0072 & 0 & 97.46 & 0.0072 & 0 & 0 & 0 & 1.69 & 0.562 & 2.97 & 0.634 & 0.909 & 0.697 & 1 \\
\hline & 2 & 0.012 & $=0.0025^{-}$ & & 0.00493 & 0.002056 & -0.000424 & 0.0000469 & 1.48 & 0.501 & 2.65 & 0.420 & 0.811 & 0.518 & 2 \\
\hline & 3 & - & 0.005 & & 0.00378 & 0.002632 & -0.000904 & 0.000158 & 1.47 & 0.491 & 2.59 & 0.284 & 0.794 & 0.358 & 3 \\
\hline & 4 & & 0.0075 & & 0.00273 & 0002942 & 0.001473 & 0.000351 & 1.47 & $0.490^{\circ}$ & 2.59 & 0.224 & 0.793 & 0.282 & 4 \\
\hline & 5 & & .01 & & 0.00197 & 0.003063 & 0.001963 & 0.000555 & 1.55 & 0.498 & 2.63 & 0.182 & 0.807 & 0.226 & 5 \\
\hline & 6 & 0.01 & 0 & & 0 al & 0 & & $a$ & 115 & 0.426 & 2.25 & 0.644 & 0.690 & 0.933 & 6 \\
\hline & 7 & & 0.0025 & & 000771 & 0.001781 & 0000258 & 0.0000197 & 1.11 & 0.402 & 2.12 & 0.431 & 0.651 & 0.662 & 7 \\
\hline & 8 & & 0.005 & & $=00592-$ & 0002616 & 0000733 & 0.000101 & 1.09 & 0.390 & 2.06 & $0.33 \mathrm{I}$ & 0.631 & 0.525 & 8 \\
\hline & 9 & & 0.0075 & & 0.00457 & 0.003018 & $000 \overline{1247}$ & 0.000247 & 1.13 & 0.393 & 2,08 & 0.264 & 0.637 & 0.14 & 9 \\
\hline & 10 & & $0 \quad 01$ & & 0.00352 & 0003212 & 0001719 & 0000430 & 1.22 & 0.415 & 2.19 & 0.213 & 0.672 & 0.317 & 10 \\
\hline & in & $0 \quad 0072$ & 0 & 9137 & 0.0072 & 0 & 0 & 0 & 326 & 0.534 & 3.90 & 0.675 & 0.864 & 0.781 & 11 \\
\hline & 12 & & 0005 & & 0.00378 & 0.002632 & 0,000904 & 0000158 & 3.85 & 0.458 & 3.35 & 0.302 & 0.742 & 0.407 & 12 \\
\hline & 13 & & 0.01 & & 0.00197 & 0003063 & 0.001963 & 0000555 & 4.28 & 0.468 & 3.42 & 0.192 & 0.758 & 0.253 & 13 \\
\hline & 14 & .01 & 0 & & 001 & 0 & $a-\cdots$ & 0 & $\frac{7.20-}{1.87}$ & 0.386 & 2.82 & 0.689 & 0.625 & 1002 & 14 \\
\hline & 15 & & $0.005^{--}$ & & 0.00592 & -0.002616 & $0000733^{-}$ & 0.000101 & 1.92 & 0.348 & 2.54 & 0.354 & 0.563 & 0.629 & 15 \\
\hline & 16 & & 0.01 & & 000352 & 0003212 & 0001719 & 0.000430 & 2.50 & 0.375 & 2.74 & 0.228 & 0.607 & 0.376 & 16 \\
\hline & 17 & 0.0072 & 0 & 87.72 & 0.0072 & --- & 0 & & 6.11 & 0.521 & 4.87 & 0.693 & 0.844 & 0.821 & 17 \\
\hline & 18 & & 0.005 & & 000378 & 0.002632 & ${ }_{0}^{\circ} 000904^{-}$ & 0.000158 & 8.24 & 0.440 & 411 & 0.313 & 0.712 & 0.140 & 18 \\
\hline & 19 & & 001 & & $0 \quad 00197$ & 0.003063 & 0.001963 & 000555 & 9.63 & 0.451 & 4.22 & 0.198 & 0.731 & 0.271 & 19 \\
\hline & 20 & .01 & 0 & 85.28 & 0.01 & 0 & 0 & $0--$ & 4.71 & 0.360 & 4.10 & 0.719 & 0.583 & 1233 & 20 \\
\hline & 21 & & 0005 & & 000592 & 0.002616 & 0000733 & 0.000101 & 4.03 & 0.323 & 3.67 & 0.368 & 0.522 & 0.705 & 21 \\
\hline & 22 & & 0.01 & & $0 \quad 00352$ & 0003212 & 0.001719 & 0.000430 & 5.29 & 0.352 & 4.00 & 0.236 & 0.569 & 0.415 & 22 \\
\hline \multirow{10}{*}{ 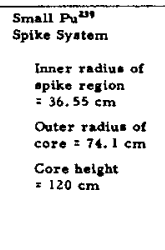 } & 23 & 0.015 & 0 & 4873 & 0.015 & 0 & $a_{-}$ & 0 & -2.58 & 0.318 & 1.68 & 0.577 & 0.515 & 1120 & 23 \\
\hline & 24 & & 0.0025 & & 0.01243 & 0001559 & 0.000180 & 0.0000118 & 2.71 & 0.322 & 1.70 & 0.426 & 0.521 & 0.818 & 24 \\
\hline & 25 & & 0.005 & - & 0.01030 & 0,002495 & 0.000515 & 0.0000565 & 2.96 & 0.327 & 1.73 & 0.343 & 0.530 & 0.647 & 25 \\
\hline & 26 & & 00075 & & 0008496 & 0.003060 & 0.000928 & 0000139 & 3.36 & $0.338^{-}$ & 1.78 & 0.283 & 0547 & 0517 & 26 \\
\hline & 27 & & 001 & & 0.006986 & 0.003385 & 0.001369 & $0000268^{-1}$ & 4.15 & 0.359 & 1.90 & 0.234 & 0.581 & 0.403 & 27 \\
\hline & 28 & 0.02 & 0 & & 0.02 & 0 & 0 & 0 & 064 & 0.154 & 0.82 & 0.598 & 0.250 & 2393 & 28 \\
\hline & 29 & & 0.0025 & & 0.01731 & 0.001415 & 0.000120 & 0.0000056 & 0.75 & $\begin{array}{r}- \\
- \\
\end{array}$ & 0.88 & 0.473 & 0.271 & 1.745 & 29 \\
\hline & 30 & & 0.005 & & 001496 & 0.002396 & 0000392 & 00000347 & 0.91 & 0.186 & 0.98 & 0.396 & 0.300 & 1320 & 30 \\
\hline & 31 & & 0.0075 & & 0.01288 & 0.003026 & 0000721 & 00000887 & 1.09 & 0.207 & 1.10 & 0.329 & 0.336 & 0.979 & 31 \\
\hline & 32 & & 0.01 & & 0.01104 & 0003467 & 0001101 & 0.000176 & 1.37 & 0.226 & 1.19 & 0.282 & 0.366 & 0.770 & 32 \\
\hline \multirow{10}{*}{ 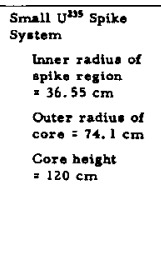 } & 33 & 0.015 & 0 & & 0.015 & 0 & 0 & 0 & 3.62 & 0.294 & 1.55 & 0.597 & 0.347 & 1719 & 33 \\
\hline & 34 & & 0.0025 & & 0.01243 & 0.001559 & 0.000180 & 0.0000118 & 3.79 & 0.298 & 1.57 & 0.441 & 0.352 & +253 & 34 \\
\hline & $\frac{35}{35}$ & & 0.005 & & 0.01030 & 0002495 & 0.000515 & 00000565 & 4.05 & 0.305 & 1.61 & 0.358 & 0.361 & 0.992 & 35 \\
\hline & 36 & & 0.0075 & & 0.008696 & 0.003060 & 0.000928 & 0000139 & 4.42 & & 1.67 & 0.292 & 0.374 & 0.781 & 36 \\
\hline & 37 & & 0.01 & & 0.006986 & 0.003385 & 0.001369 & 0.000268 & 5.04 & 0.333 & 1.76 & 0.244 & 0.394 & 0.619 & 37 \\
\hline & 38 & 0.02 & $\circ$ & - & 002 & 0 & $\overline{0}-7$ & 0 & 122 & 0.142 & 0.75 & 0.607 & 0.168 & 3611 & 38 \\
\hline & 39 & & 0.0025 & & 0.01731 & 0001415 & 0.000120 & 0.0000056 & 1.42 & 0.162 & 0.86 & 0.476 & 0.192 & 2479 & 39 \\
\hline & 40 & & 0.005 & & 0.01496 & 0.002396 & 0.000392 & 0.0000347 & 1.81 & 0.179 & 0.94 & 0.399 & 0.211 & 1891 & 40 \\
\hline & $\frac{71}{41}$ & & 0.0075 & & 001288 & 0.003026 & 0.000721 & 00000897 & 2.30 & 0.202 & 1.07 & 0.332 & 0.238 & 1395 & 42 \\
\hline & 42 & & 0.01 & & 0.01104 & 0.003467 & 0001101 & 0.000176 & 3. 21 & 0.231 & 1.22 & 0.280 & 0.274 & 1022 & 42 \\
\hline
\end{tabular}

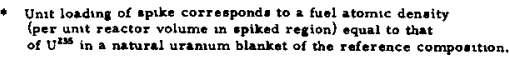




\section{DISCUSSION OF RESULTS AND CONCLUSIONS ON SPIKED PLUTONIUM RECYCLE SYSTEMS}

The conclusions relative to the spiked system are primarily deduced from the results summarized in Table 15. The main quantities to consider in evaluation of the system are: the blanket enrichment $\left(E_{0}\right)$, the blanket reject burnup $(B)$, the reject $U^{235}$ concentration, the production ratio $(P R)$, and the ratio $\left(P_{D S}\right)$ of average power density in the spike to average power in the entire core including both spikes and blanket. A value of 1.8 for $P_{D S}$ is about the highest that can be tolerated without hurting the average power appreciably; this rather arbitrary estimate is based on the prediction that EBWR with a spiked loading is capable of producing $100 \mathrm{Mw}$ with that value for $P_{D S}$.

Evaluation of the potential of the concept is best made by consideration of the characteristics of the larger systems. An inspection of the results of the large cases shows that none of them represents a satisfactory system. In general, all have excessively high power densities in the spikes. The production ratios are all substantially less than unity unless the blankets have extremely short burnups and the power densities in the spikes are high. The production ratios all drop rapidly with burnup.

In general, the results given in Table 15 appear worse for the large system than they do for the small system. This is not because the large system is inherently worse, but rather follows from the lower blanket enrichments that have been considered for the large system. The rapid drop in the production ratio with burnup is basically a property of lowenrichment blankets rather than of large systems.

Perhaps the best large case lies between Cases 14 and 15 - corresponding to $\mathrm{E}_{0}=0.01, \mathrm{~B} \approx 0.001(\sim 1000 \mathrm{Mwd} / \mathrm{ton}), \mathrm{PDS} \sim 2.75$, and $\mathrm{PR} \sim 1$.

At first glance an inspection of the results in Table 15 for the small, EBWR-size cases appear to show more encouraging results than for the large systems. For example, Case 31 has rather satisfactory operating characteristics with $E_{0}=0.02, B=0.0075$ ( 7500 Mwd/ton), PDS 1.1, and $\mathrm{PR} \sim 1$. However, in terms of feasibility of the spiked concept, the satisfactory characteristics of this case are not too meaningful since the spikes play an unimportant role. The characteristics of Case 31 could essentially be obtained with a uniform loading of a correspondingly high enrichment, $E_{0}=0.02$. For demonstration of feasibility, the enrichment must be substantially lower than that required for the uniform loading.

If one goes from Case 31 towards a case where the spikes have a larger effect because of a lower blanket enrichment, say $E_{0}=0.015$, one can then only obtain an irradiation of the order of $B \approx 0.0015(\approx 1500 \mathrm{Mwd} /$ ton) if $P R \sim 1$ is required; this corresponds to a system between Cases 23 and 24, which would have a value of $\mathrm{P}_{\mathrm{DS}} \sim 1.7$. 
We thus see that satisfactory power distributions can be obtained for both large and small systems only by enriching the blanket material. Plutonium recycle $(P R \geq 1)$ can be obtained with very low-enrichment blankets only if the blanket irradiations are kept unreasonably low. Values of PR as large as desired can be obtained by going to higher blanket enrichments (so that the spikes are unimportant).

Interpreting the results in terms of EBWR, one finds that spiked operation with natural uranium feed is not possible if a total power of the order of $100 \mathrm{Mw}$ is desired. This conclusion is based on the premise that only a reasonably small number of spiked elements ( $\sim \frac{1}{4}$ of the core) are used. Operation is not possible from reactivity considerations alone, quite apart from any questions of desirable characteristics. The reason for the low reactivity is that at the high power densities at which the spikes must operate they become excessively voided and thus lower the reactivity.

The discouraging conclusions on both the general feasibility of the concept and on the possibility of $100-\mathrm{Mw}$ operation for EBWR with this loading have led to a suspension of plans for a loading of this type of EBWR.

In view of these rather pessimistic conclusions on the feasibility of plutonium recycle in this type of system, it is of interest to consider what generalizations, if any, can be made about plutonium recycle in general as a result of this study.

It is well known that plutonium recycle calculations are complicated. The main reason for the complexity and difficulty in making general conclusions about the calculations are the many possible relevant variables. Among these are the type of fuel, type of fertile material, general composition of the system, and length of irradiation. There is also the entire complex of problems associated with fuel-management procedures. There may be periodic partial unloading of the core and/or periodic movement of fuel from one region of the reactor to another. In addition, there are the complications arising from uncertainties in cross sections.

The basic conclusion of the study has been that plutonium recycle with natural uranium feed is not feasible in a light water-boiling system fueled with uranium dioxide elements even if spiked configurations are allowed. This conclusion remains valid even if we consider systems much larger than EBWR. We have also found that the use of slightly enriched, rather than natural, feed does not improve matters in any real sense. It is no longer true that plutonium recycle is impossible, since obviously a feed material sufficiently enriched can be used so that the spiked elements are essentially unnecessary for the operation of the system. Then, clearly, the plutonium that is removed from the blanket is sufficient for replenishing the spikes. When we further consider other variables, such as the fraction of the original $\mathrm{U}^{235}$ loaded into the system that is consumed prior to rejection of the feed material, however, we find that the use of higher enriched material for the feed has not appreciably improved matters. 
The number of variables is large and there are, of course, uncertainties in making more general conclusions than may be directly inferred from the cases that have been considered. In the present study, however, the conclusions have been so clear-cut that it is justifiable to generalize to some extent.

The generalization to a pressurized system rather than a boiling system and/or using uranium metal rather than oxide fuel can safely be made. The improved neutron economy inherent with both the nonboiling operation and the metal-feed operation would in both cases tend to improve the picture, but probably only to a slight extent. The basic conclusion of the nonfeasibility of plutonium recycle operation on a self-sustaining basis with natural uranium feed is probably generally applicable to light watermoderated thermal reactors. The reasons for this can ultimately be traced to considerations of neutron economy. The use of plutonium in a thermal system starts out with a large inherent disadvantage due to the large capture-to-fission ratio of plutonium at thermal energies. With the added poor neutron economy inherent with light water moderation, the effect of the combination of the two is too great to permit self-sustaining operation with natural uranium feed.

It is of interest to compare our results with other studies on the same general subject. We find that although our results appear to be somewhat more pessimistic than those obtained elsewhere, in general the conclusions are not too much different. Greebler et al. (Ref.9) have reported on a study of plutonium recycle in a boiling water oxide system. Their conclusions, even though more optimistic than ours, were nevertheless quite discouraging for natural uranium operation. Due to uncertainties in the fundamental data and in operating procedures, they considered three values for the operating reactivity: $1.03,1.04$, and 1.05 . These values do not include $\mathrm{Xe}$ and $\mathrm{Sm}$ reactivity losses, estimated to be 0.04 . They found that for the uniformly loaded system, using the optimistic operating reactivity 1.03 , the permissible blanket irradiation for self-sustaining operation with natural uranium feed was $4000 \mathrm{Mwd} / \mathrm{ton}$. This result is considerably more optimistic than is deducible from our results. Even so, their conclusion about natural uranium feed was discouraging, since the cycle cost for the natural uranium feed case was almost twice that for the optimum slightly enriched case. It is somewhat difficult to ascertain exactly why the Greebler et al. results, even though quite pessimistic, are more optimistic than ours. It appears that the discrepancies are primarily due to choice of cross sections and estimates of required operating reactivity. The cross sections used in our study are less reactive than those used in the Greebler et al. analysis. The justification for the cross sections we have used is based primarily on the numbers necessary for agreement with EBWR, which experimentally is observed to be less reactive than calculated with a priori cross sections. 
Another relevant study is the Armour study(1) on EBWR. These results are considerably closer to ours than are the results of Greebler et al. (9) There is, however, one major disagreement between our results and those of Armour. They conclude that self-sustaining operation is possible with natural uranium feed in EBWR operating at $100 \mathrm{Mw}$ although only with an extremely short ( several hundred Mwd/ton) blanket irradiation. Our conclusion is that such operation is not posible at all. The different conclusions are attributable to initially selected ground rules for the calculations. In the Armour study, a uniform void distribution throughout the core was assumed, an assumption not made in our study. The high power densities in the spiked elements result in appreciably increased void fractions in the spikes and thus lead to a considerable reduction in overall reactivity. 


\section{STUDY OF UNIFORM AND TWO-ZONE SYSTEMS}

The assumed core void distributions in the study of the uniform and two-zone systems were:

\begin{tabular}{|c|c|c|c|}
\hline \multicolumn{2}{|c|}{ Uniform } & \multicolumn{2}{|c|}{ Two-zone } \\
\hline Region & Void & Region & Void \\
\hline I & 0.3 & I & 0.25 \\
\hline II & 0.21 & II & 0.25 \\
\hline
\end{tabular}

Region I contains the innermost $8 \times 8$ square array of fuel elements in EBWR, region II the remainder of the core. The voids are representative of EBWR operation at $100 \mathrm{Mw}$.

Table 16 gives the equilibrium characteristics of several of the homogeneous and two-zone cores studied. The two-zone cases studied had enrichment ratios of 1.333 and 1.5 (the higher value always being in the outer zone). The average initial blanket enrichments $\bar{E}_{0}$ necessary to attain various burnups B (fissions per original uranium atom) in the reject material were determined. The radial power distributions, characterized in Table 15 by $\overline{\mathrm{P}}_{\mathrm{II}} / \overline{\mathrm{P}}_{\mathrm{I}}$ (ratio of average power in region II to average power in region $\mathrm{I}$ ) and by the ratios of the power at the center, zone interface, and outer edge to the average power were also determined. The maximum power was in all cases at one of these three positions. The power peaks at the outermost edge of the core need not be taken seriously, since they are very sharply attenuated transients and can be avoided by localized poison.

Table 16

\section{EQUILIBRIUM CHARACTERISTICS OF HOMOGENEOUS AND TWO-ZONE CORES}

\begin{tabular}{|c|c|c|c|c|c|c|}
\hline & Burnup & $\bar{E}_{0}$ & $\overline{\mathrm{P}}_{\mathrm{II}} / \overline{\mathrm{P}}_{\mathrm{I}}$ & $\frac{P(\text { center })}{\overline{\bar{P}}}$ & $\frac{P \text { (interface) }}{\bar{P}}$ & $\frac{P \text { (outer edge) }}{\overline{\mathrm{P}}}$ \\
\hline Uniformly & 0 & 0.0165 & 0.640 & 1.519 & 1.045 & 0.929 \\
\hline Enriched & 0.005 & 0.0174 & 0.651 & 1.504 & 1.043 & 1.003 \\
\hline \multirow[t]{3}{*}{ Core } & 0.01 & 0.0192 & 0.661 & 1.490 & 1.040 & 1.065 \\
\hline & 0.015 & 0.0216 & 0.668 & 1.479 & 1.038 & 1.114 \\
\hline & 0.02 & 0.0243 & 0.675 & 1.468 & 1.037 & 1.162 \\
\hline \multirow[t]{5}{*}{$\mathrm{E}_{0}^{I I} / \mathrm{E}_{0}^{\mathrm{I}}=1.333$} & 0 & 0.0172 & 0.728 & 1.408 & 1.199 & 1.084 \\
\hline & 0.005 & 0.0181 & & & & \\
\hline & 0.01 & 0.0199 & & & & \\
\hline & 0.015 & 0.0223 & & & & \\
\hline & 0.02 & 0.0250 & & & & \\
\hline \multirow[t]{5}{*}{$E_{0}^{I I} / E_{0}^{I}=1.5$} & 0 & 0.0179 & 0.849 & 1.247 & 1.280 & 1.222 \\
\hline & 0.005 & 0.0188 & & & & \\
\hline & 0.01 & 0.0206 & & & & \\
\hline & 0.015 & 0.0230 & & & & \\
\hline & 0.02 & 0.0257 & 0.861 & 1.220 & 1.235 & 1.477 \\
\hline
\end{tabular}


It may be seen that there is substantial advantage in the use of different enrichments in two radial zones for the purpose of power flattening. A ratio of enrichments $E_{0}^{I I} / E_{0}^{I}=1.5$ appears to be about optimum. In order to obtain a reject burnup of $B=0.02(-20,000 \mathrm{Mwd} /$ ton), an average enrichment $\bar{E}_{0} \approx 0.025$ is required. The average enrichment is only slightly increased over the enrichment of a uniform loading.

Since the various designs considered in Table 16 require considerable excess reactivity above the clean condition in order to reach the specified burnups, some means must be found to hold down the system before equilibrium is attained. The control rods in EBWR are at best only adequate to compensate for the reactivity change from cold to operating conditions and therefore cannot be counted on for any long-term burnup effects. Table 17 lists the amount of poison (as might be supplied by a burnable poison) required to hold down the system at the initial condition and at various intermediate points in the approach to equilibrium. The unit for the amount of poison is that concentration which gives an equal thermal absorption cross section to that of $\mathrm{U}^{235}$ when the enrichment of $\mathrm{U}^{235}$ (in the reference fuel element), $\mathrm{E}_{0}=0.072$.

Table 17

BURNABLE POISON REQUIREMENTS OF HOMOGENEOUS AND TWO ZONE CORES

\begin{tabular}{|c|c|c|c|c|c|c|c|c|c|c|}
\hline & \multirow[b]{2}{*}{$\begin{array}{l}\text { Final } \\
\text { Burnup }\end{array}$} & \multirow[b]{2}{*}{$\bar{E}_{0}$} & \multicolumn{2}{|c|}{ At Burnup 0} & \multicolumn{2}{|l|}{ At Burnup } & \multicolumn{2}{|l|}{ At Burnup } & \multicolumn{2}{|l|}{ At Burnup } \\
\hline & & & $\begin{array}{c}\text { Keff without } \\
\text { Burnable } \\
\text { Poison } \\
\end{array}$ & $\begin{array}{c}\text { Burnable } \\
\text { Polson } \\
\text { Required }\end{array}$ & $\begin{array}{c}\text { Keff without } \\
\text { Burnable } \\
\text { Poison } \\
\end{array}$ & $\begin{array}{c}\text { Burnable } \\
\text { Poison } \\
\text { Required }\end{array}$ & $\begin{array}{l}\text { Keff without } \\
\text { Burnable } \\
\text { Poison } \\
\end{array}$ & $\begin{array}{c}\text { Burnable } \\
\text { Polson } \\
\text { Required }\end{array}$ & $\begin{array}{l}\text { Keff without } \\
\text { Burnable } \\
\text { Poison }\end{array}$ & $\begin{array}{c}\text { Burnable } \\
\text { Porson } \\
\text { Required }\end{array}$ \\
\hline Uniformly Enriched & 0005 & 00174 & & 00053 & 1 & 0 & - & & & \\
\hline Core, Uniformly & 001 & 00192 & & 00156 & & 00097 & 1 & 0 & & \\
\hline Distributed Poison & $\begin{array}{l}0015 \\
002\end{array}$ & $\begin{array}{l}00216 \\
00243\end{array}$ & & $\begin{array}{l}00292 \\
00447\end{array}$ & & $\begin{array}{l}00227 \\
00372\end{array}$ & & $\begin{array}{l}00126 \\
00271\end{array}$ & 1 & $\begin{array}{c}0 \\
00140\end{array}$ \\
\hline $\begin{array}{l}E_{0}^{\prod_{l}} \mathrm{I} \quad 1333 \\
\text { Uniformly Distributed }\end{array}$ & $\begin{array}{l}0005 \\
001\end{array}$ & $\begin{array}{l}00181 \\
00199\end{array}$ & & $\begin{array}{l}00055 \\
00145\end{array}$ & 1 & $\begin{array}{c}0 \\
00092\end{array}$ & 1 & 0 & & \\
\hline Polson & $\begin{array}{l}0015 \\
002\end{array}$ & $\begin{array}{l}00223 \\
00250\end{array}$ & & $\begin{array}{l}00276 \\
00427\end{array}$ & & $\begin{array}{l}00213 \\
00352\end{array}$ & & $\begin{array}{l}00122 \\
00257\end{array}$ & 1 & $\begin{array}{c}0 \\
00161\end{array}$ \\
\hline $\begin{array}{l}\mathrm{E}_{0}^{\prod_{1}} \mathrm{E}_{0}^{I}{ }_{1}^{15} \\
\text { Polson }\end{array}$ & $\begin{array}{l}0005 \\
001 \\
0015 \\
002\end{array}$ & $\begin{array}{ll}0 & 0188 \\
0 & 0206 \\
0 & 0230 \\
0 & 0257\end{array}$ & 1093 & 00428 & l 074 & 00359 & 1051 & 00256 & 1023 & 00120 \\
\hline
\end{tabular}

The effect of uniform and nonuniform distributions of burnable poison in the clean condition for the case where allowance is made to reach a burnup $B=0.02$ and for a nonuniform fuel distribution, $E_{0}^{I I} / E_{0}^{I}=$ 1.333 , is given in Table 18 .

Table 18

EFFECT OF BURNABLE POISON DISTRIBUTION ON TWO-ZONE CORE $\left(E_{0}^{I I} / E_{0}^{I}=1.5\right)$

\begin{tabular}{|c|c|c|c|c|c|c|}
\hline & $\frac{{\text { Burnable Poison })^{I I}}_{(\text {Burnable Poison })^{I}}}{\text { (B. }}$ & $\begin{array}{c}\text { Average } \\
\text { Burnable } \\
\text { Poison }\end{array}$ & $\overline{\mathrm{P}}_{\mathrm{II}} / \overline{\mathrm{P}}_{\mathrm{I}}$ & $\frac{P(\text { center })}{\bar{P}}$ & $\frac{P \text { (nterface) }}{\bar{P}}$ & $\frac{\mathrm{P} \text { (outer edge) }}{\overline{\mathrm{P}}}$ \\
\hline Burnup $=0$ & $\begin{array}{l}1 \\
1.25 \\
1.5\end{array}$ & $\begin{array}{l}0.0407 \\
0.0428 \\
0.0452\end{array}$ & $\begin{array}{l}0.880 \\
0.832 \\
0.784\end{array}$ & $\begin{array}{l}1.204 \\
1.268 \\
1.341\end{array}$ & $\begin{array}{l}1.273 \\
1.271 \\
1.268\end{array}$ & $\begin{array}{l}1.445 \\
1.395 \\
1340\end{array}$ \\
\hline Burnup $=0.02$ & - & 0 & 0.861 & 1.220 & 1.235 & 1477 \\
\hline
\end{tabular}


Even though a nonuniform fuel distribution has the advantage of flattening the power distribution, it has the accompanying disadvantage of reducing the control rodworth in EBWR, because the rods are then all located in the inner lower enrichment zone. This disadvantage can be partially overcome by distributing the burnable poison nonuniformly with a higher value in the outer zone. The results of a study of this effect are given in Table 19. The control rod worths [calculated by $P D Q$ in (X, Y) geometry] are all evaluated in the clean cold condition.

Table 19

CONTROL ROD WORTH FOR VARIOUS DISTRIBUTIONS OF FUEL AND BURNAB LE POISON

$\begin{array}{cccccc}E_{0}^{I I} / E_{0}^{I} & \text { PoisonII/Poison } & & E_{0}^{I I} & \begin{array}{c}\text { Average } \\ \text { Burnable } \\ \text { Poison }\end{array} & \begin{array}{c}\text { Control Rod } \\ \text { Worth }\end{array} \\ 1 & 1 & 0.03 & 0.0708 & & 0.121 \\ 1.5 & 1 & 0.036 & 0.0708 & & 0.083 \\ 1.5 & 1.5 & 0.036 & 0.0708 & & 0.102\end{array}$


1. W. E. Lowe et al., The Physics of EBWR as a Natural Uranium Oxide Power Converter, ARF-1160-1 (June 1, 1960).

2. R. Avery, K. Almenas, C. Carson, H. Iskenderian, and C. Kelber, EBWR Core IA Physics Analysis, ANL-6305 (1960).

3. H. Amster and R. Suarez, The Calculation of Thermal Constants Averaged over a Wigner-Wilkins Flux Spectrum, WAPD-TM-39 (January 1957).

4. H. Amster, A Compendium of Thermal Neutron Cross Sections Averaged over the Spectra of Wigner and Wilkins, WAPD-185.

5. ANL-5800, Reactor Physics Constants.

6. A. R. Vernon, Calculation of the Effective Resonance Integral of $\mathrm{U}^{238}$, Nuc. Sci. and Eng., I, 252-259 (1960).

7. A. L. MacKinney and R. M. Ball, Reactivity Measurements on Unperturbed Slightly Enriched Uranium Dioxide Lattices, Trans. Am. Nuc. Soc., 3(1), pp. $72-75$ (June 1960).

8. B. I. Spinrad, J. C. Carter, and C. Eggler, Reactivity Changes and Reactivity Lifetimes of Fixed-Fuel Elements in Thermal Reactors, Proc. of 1955 Geneva Conf., Vol. 5, pp. 125-140; United Nations, New York (1955).

9. P. Greebler et al., Recycle of Plutonium in Low-enrichment Light-water Reactors, Proceedings of the Second United Nations International Conference on the Peaceful Uses of Atomic Energy, Geneva, Switzerland (1958), Vol. 13, p. 251 . 